\title{
In Vitro and In Vivo Testing Methods of Epigenomic Endpoints for Evaluating Endocrine Disruptors
}

\author{
John M. Greally ${ }^{1}$ and Miriam N. Jacobs ${ }^{2}$ \\ ${ }^{1}$ Center for Epigenomics, Albert Einstein College of Medicine, Bronx, NY, USA; ${ }^{2}$ Scientific Committee and Emerging Risks Unit, \\ European Food Safety Authority - EFSA, Scientific Committee Unit, Parma, Italy
}

\begin{abstract}
Summary
Epigenetic modulations underlie critical developmental processes and contribute to determining adult phenotype. Alterations to the phenotype, due to exposure to environmental insults during sensitive periods of development, are mediated through alterations in epigenetic programming in affected tissues. Originally prepared for the Organisation of Economic Cooperation and Development (OECD), this detailed review evaluates the potential role of chemical-induced epigenetic modifications to endocrine signaling pathways during sensitive windows of exposure as a mechanism of endocrine disruption, along with the examination of potential methods for assessing such disruption. Potential targets of disruption along putative adverse outcome pathways associated with the signaling pathways are identified, along with assays that show promise in evaluating the target in a screening and testing program such that in vitro methods are used where possible, and animal experiments only where in vitro methods are not available. Monitoring such epigenetic marks in response to toxicant exposure may in future provide a valuable tool for predicting adverse outcomes, but a more robust basis for Test Guideline recommendations is still needed. Although there is evidence to suggest that epigenomic dysregulation might mediate effects of exposures to endocrine disruptors, it is uncertain as to whether these changes are truly predictive of adverse outcome(s). Adverse effects observed in the OECD transgenerational assays could be used to inform future tests specifically designed to investigate the epigenetic mechanism of action. Follow-up studies should include both an epigenetic as well as a genomic component to differentiate between the contributions of potentially compensatory mechanisms.
\end{abstract}

Keywords: endocrine disruptors, endocrine active substances, epigenome, regulatory methods, toxicity testing

\section{Introduction'}

The mechanism by which the group of chemicals referred to as "endocrine disruptors" exert their phenotypic effects remains only partially understood, but there is emerging evidence that dysregulation of the cell's epigenome is involved. In the last decade, it has become clear that the emerging field of epigenetics is of significant relevance for both the study and practice of toxicology and safety assessment. At the research level, these efforts currently aim to elucidate the involvement of chemicalinduced epigenetic changes in adverse health effects, as well as to enable the exploitation of epigenetics particularly in the area of in vitro and in vivo modeling. While there have been plenty of reports linking endocrine disruptors with phenotypic abnormalities in wildlife, there are currently no publications describing epigenetic studies in wildlife undergoing these exposures.

Received February 21, 2013; accepted in revised form June 4, 2013; Epub June 20, 2013

Disclaimer: This paper is published under the sole responsibility of the authors and may not be considered as an EFSA output and is not intended to represent the views of EFSA. The paper is based on the annex of OECD (2012), Detailed Review Paper on the State of the Science on Novel In Vitro and In Vivo Screening and Testing Methods and Endpoints for Evaluating Endocrine Disruptors, Series on Testing and Assessment, No. 178, OECD, Paris.

The use of trade names is for identification only and does not constitute endorsement by the authors, EFSA, OECD, or the Albert Einstein College of Medicine.

1Abbreviations

BPA, bisphenol A; CG/CpG, cytosine-guanine dinucleotide; ChIP, chromatin immunoprecipitation; DNMT, DNA methyltransferase; ED, endocrine disruptor; EDTA-AG, OECD Endocrine Disruptor Testing and Assessment Advisory Group; ENCODE, ENCyclopedia Of DNA Elements; ES, embryonic stem; EZH2, enhancer of zeste homolog 2; IAP, intracisternal A particle; IUGR, intrauterine growth restriction; miRNA, micro RNA; MPS, massively-parallel sequencing; OECD, Organisation for Economic Cooperation and Development; TG, Test Guideline 
While wildlife and ecotoxicological aspects are not specifically addressed in this paper, some of the models discussed also may be relevant for these areas. This paper reviews our current understanding of the intersection of these two fields of research and proposes avenues of exploration encompassing epigenetic information that will form the foundation for definitive testing of this relationship and provide a basis for future practical and predictive applications for regulatory safety assessment.

The issue of incorporation of epigenetic evaluations into safety assessments has been reviewed in recent times (Goodman et al., 2010), with the conclusion that the rapidly-developing field of epigenetics shows promise as a means of gaining insights into the effects of endocrine disruptors upon human health, but that there remains a lot to be learned before it is clear how these tests should be applied, and how they can be developed with respect to the 3R's principles: to reduce, refine, and replace the use of animals in testing of chemicals. How to eventually incorporate the understanding of epigenetic mechanisms into the OECD chemical safety assessment regulatory activities and how this might be done within the ED conceptual framework in vitro screening, priority, and definitive in vivo testing levels, is the major challenge and objective that this paper begins to explore and address. The paper was therefore developed in close cooperation with the OECD advisory group on testing and assessment of endocrine disrupters (EDTA-AG), as an annex to a detailed review paper: "State of the Science on Novel In Vitro and In Vivo Screening and Testing Methods and Endpoints for Evaluating Endocrine Disruptors" (OECD, 2012a). The EDTAAG was established to direct and oversee the development of new or revised Test Guidelines (TGs) for the detection of endocrine active chemicals and endocrine disruptors, as part of the Test Guideline Programme.

\section{Definitions}

\subsection{Endocrine disruptors}

In the context of the OECD Guidance Document (GD) No. 150 on Standardised Test Guidelines for Evaluating Chemicals for Endocrine Disruption (OECD, 2012a), an endocrine disrupter (ED) has been defined according to WHO/IPCS (2002), i.e., "An ED is an exogenous substance or mixture that alters function(s) of the endocrine system and consequently causes adverse health effects in an intact organism, or its progeny, or (sub)populations." WHO/IPCS (2002) also defines the term "potential ED" such that "A potential endocrine disruptor is an exogenous substance or mixture that possesses properties that might be expected to lead to endocrine disruption in an intact organism, or its progeny, or (sub)populations." It is acknowledged that many other definitions exist (e.g., Weybridge Conference, 1996), but the WHO/IPCS (2002) definition has been used as a working definition for the GD document because it covers both human health and wildlife populations. This widely used, but not universally accepted, definition is also used in this paper. Furthermore, for the purposes of the GD it was agreed by the EDTA-AG to operationally define the term "possible ED" to mean a chemical that is able to alter the functioning of the endo- crine system but for which information about possible adverse consequences of that alteration in an intact organism is uncertain (OECD, 2012b).

\subsection{The epigenome}

The word "epigenome" is derived from "epigenetics," a term attributed to Waddington (1942) who defined it as "the branch of biology which studies the causal interactions between genes and their products, which bring the phenotype into being." Waddington was looking for an explanation of how the same genome could be used to generate different cell types in multicellular organisms, suggesting a higher level of regulation acting on nonautonomous genes. The term "epigenetic" was resurrected more recently as a broad description of heritable processes that do not depend on changes in DNA sequence, to include phenomena such as genomic imprinting and $\mathrm{X}$ chromosome inactivation. In each of these examples, a locus on one of the two homologous chromosomes, almost identical (or completely identical in inbred mouse strains) in terms of DNA sequence, is silenced, with the other active. This is a state that remains stable from parent to daughter cells, thus the heritability component.

Some of the molecular mechanisms implicated in allelic silencing include methylation of DNA (Sapienza et al., 1989), histone modifications and variant deposition (Delaval and Feil, 2004), DNA replication timing (LaSalle and Lalande, 1996), antisense, and non-coding RNA transcription (Whitehead et al., 2009) among others (see below). Of these, only DNA methylation had a demonstrable biochemical mechanism for parent to daughter cell propagation of its regulatory message (maintenance DNA methyltransferase, DNMT1; Goyal et al., 2006), making DNA methylation the standard bearer for an epigenetic regulator. This is mostly because of a current dearth of knowledge about how other mechanisms may be heritable, which may in time be revealed, but is at present elusive.

"Epigenome" represents the collective noun to describe the sum of the epigenetic modifications throughout the genome. This is where the common use of the term deviates from the strict definition, as the term describes molecular mediators and not heritable influences on cellular properties. As such, the term describes a broad group of transcriptional regulatory processes, of which only DNA methylation is demonstrably heritable mitotically. Whilst considered by some scientists to be an incorrect use of the term (Ptashne, 2013), it is however useful, as there is no other obvious term that describes the broad group of transcriptional regulatory processes, including chromatin and DNA properties, that gets across the idea that some of these properties may mediate a cellular memory.

This paper utilizes the terms "epigenetic" and "epigenome", as commonly used to describe the full spectrum of transcriptional regulatory processes that appear to mediate environmental influences and change a cellular state to reflect past exposures.

\subsection{Epigenomic regulatory mechanisms}

The molecular mechanisms believed to mediate epigenetic and transcriptional regulation are diverse (overview in Tab. 1).

What these regulators have in common is a lack of innate DNA sequence specificity (with the possible exception of cer- 
Tab. 1: Examples of molecular regulators of the vertebrate epigenome

\begin{tabular}{|l|l|l|}
\hline Molecular mediator & Example & References \\
\hline Histone post-translational modifications & $\begin{array}{l}\text { Histone H3 lysine 9 trimethylation (H3K9me3), } \\
\text { a repressive mark }\end{array}$ & Hiragami-Hamada et al., 2009 \\
\hline Histone variants & Histone Macro H2A.1 & Bernstein et al., 2008 \\
\hline Nucleosome positioning & Nucleosome-free regions at gene promoters & Hartley and Madhani, 2009 \\
\hline Chromatin looping & Kit regulation by Gata1/Gata2 & Jing et al., 2008 \\
\hline DNA modifications & Cytosine methylation & Klose and Bird, 2006 \\
\hline DNA structural variation & R-loop formation & Roy et al., 2008 \\
\hline RNA-mediated & Antisense RNA transcription & Beiter et al., 2009 \\
\hline
\end{tabular}

tain DNA methyltransferases which may preferentially target certain CG dinucleotide periodicities; Jia et al., 2007). To exert sequence-specific events, it is likely that transcription factors and other DNA-binding proteins with sequence preferences help to recruit modifying enzyme complexes (Beckerman and Prives, 2010), one of the ways that the boundary between transcriptional and epigenetic regulators blurs in terms of functions. Another source of sequence-specificity may be the endogenous short interfering RNAs (siRNAs) that have been found to induce heterochromatinization in plants and yeast (Pikaard, 2006; Zofall and Grewal, 2006). Although there has been little evidence for such mechanisms in mammalian cells in the past (Kim et al., 2006; Morris et al., 2004), there is now increasing evidence for siRNA induced heterochromatin in mammals too (Santenard et al., 2010).

As mentioned earlier, only DNA methylation has a molecular mechanism defined that allows it to act in a heritable manner from parent to daughter cells. The DNA methyltransferase 1 enzyme (DNMT1) has the ability to recognize (with the chromatin protein UHRF1) loci where a symmetricallymethylated CG dinucleotide (methylation on both the Watson and Crick strands) becomes hemi-methylated following DNA replication (which introduces an unmethylated cytosine when creating the new complementary strands of DNA) and restores the locus to symmetrical methylation on both daughter chromatids. This maintenance methyltransferase function thus allows a methylation mark in a parent cell to be maintained in both daughter cells.

The stability of other putative epigenetic regulators in populations of growing cells suggests that they can also maintain themselves in a site-specific manner through DNA replication, potentially through the association of enzymes with chromatin through DNA replication, as demonstrated using an in vitro system (Francis et al., 2009). RNA-mediated effects such as paramutation, best described in plants (Chandler, 2007), have been observed in mice (Rassoulzadegan et al., 2006), although it is unclear how RNA molecules can self-replicate in mammals which appear to lack the RNA-dependent RNA polymerase needed for paramutation in plants (Alleman et al., 2006).

While the molecular basis for the maintenance of epigenomic marks at a locus in dividing or post-mitotic cells remains largely unknown, the stability of these marks is well-recognized and suggests that the failure to find maintenance mechanisms does not mean that they do not exist but that they are eluding our scrutiny.

\subsection{Influences exerted by epigenomic regulatory mechanisms}

The primary means by which the genome communicates its information is through transcription, so it should not be surprising that the major outcome of epigenomic regulators is usually viewed as gene expression. When histone post-translational modifications are referred to as active or repressive marks, it is in terms of local gene expression.

It becomes more complicated - the relationship of a chromatin mark with a gene activity is also dependent on the genomic context of that mark. For example, the histone H3 lysine 9 trimethylation (H3K9me3) mark is recognized as repressive when associated with heterochromatin on a cytological scale (Peters et al., 2002) and with gene silencing when present in the context of a gene promoter. However, the same modification is found to be enriched in the bodies of actively-transcribed genes (Vakoc et al., 2005), the opposite correlation in a different genomic context. The same has been found for DNA methylation, increased at promoters of silent genes but also increased in the transcribed bodies of highly-expressed genes (Ball et al., 2009). This contextual information is important when defining relationships of epigenomic regulatory marks and transcription.

Epigenomic regulation has also been associated with other genomic properties. DNA replication occurs at different times in the cell cycle in different genomic regions, with specific patterns of timing defining some regions as early and others latereplicating. Even at the cytological scale it is apparent that silencing marks are enriched at later-replicating regions and vice versa. Meiotic recombination in humans has been linked to germline DNA methylation patterns (Sigurdsson et al., 2009), and has been more precisely mapped to areas of open chromatin in yeast (Kauppi et al., 2004). Decreased global DNA methylation in mammalian cells has been linked causally to chromosomal instability (Karpf and Matsui, 2005), while mutations of the DNMT3B maintenance DNA methyltransferase causes distinctive chromosomal morphological abnormalities 
(Hansen et al., 1999). The highly abnormal nuclear morphology of B lymphocytes infected with Epstein-Barr virus reflects a profound disturbance of DNA methylation globally in these cells (Grafodatskaya et al., 2010), indicating that even cytological-scale morphology has regulatory input by these epigenomic mediators.

Recently there has been an unexpected relationship revealed between chromatin organization (Vakoc et al., 2005) or DNA methylation (Laurent et al., 2010) and the exonic organization of genes. This is unexpected because at the stage of generation of the primary transcript the gene might be expected to be agnostic regarding where splicing is occurring, an event that occurs distantly from the gene within the nucleus, an assumption that has been refined in recent years (Schwartz and Ast, 2010). In spite of this, the patterns of nucleosomal positioning (Tilgner et al., 2009) and DNA methylation observed at intron/ exon boundaries have been shown to be distinctive (Laurent et al., 2010). This raises the possibility that epigenomic regulators could be influencing splice isoform choices made in a cell type, which could have significant functional consequences for the cell. This relationship has yet to be proven rigorously, but represents an intriguing avenue of exploration.

\subsection{Large-scale studies of the epigenome}

With the large number of regulators involved, each causing potentially different organization, not only in the several hundred cell types within the body but also in the same cell types over time and in different sexes (Fraga et al., 2005; Thompson et al., 2010a), it is clear that there is a very large number of potential epigenomes for each organism. As a further complicating factor, we do not understand how to interpret many of the regulatory marks in different genomic contexts, so that even if we could catalogue epigenomes, understanding their meaning would remain difficult.

With these issues in mind, there are several large-scale initiatives to study epigenomic organization. The ENCyclopedia Of DNA Elements (ENCODE) is a project focused on understanding the function of non-coding DNA sequences in the genome, starting originally with transformed human cell lines and expanding through the modENCODE project to include primary cells from model organisms. This project has involved technology development, a lot of mapping, and insights through the development of new, sophisticated analytical approaches. This created a foundation for the Roadmap in Epigenomics, which was set up to differ in terms of a focus on primary, non-diseased human cell types, but also includes technology development and analytical aspects. The Cancer Genome Atlas (TCGA) represents another substantial project that includes an epigenomic component, but the focus in this case is not solely the epigenome. Finally the International Human Epigenome Consortium (IHEC) is in an early stage of development but plans to bring the Roadmap in Epigenomics concept a step further by looking specifically at human diseases. Table 2 lists these initiatives and web-based resources for the reader to explore further.

These projects provide insights into how epigenomes are organized, and how epigenomic information interacts with genetic polymorphism (Kasowski et al., 2010; McDaniell et al., 2010). While insights into the epigenomic organization of a specific human cell type can be gained from the Roadmap project, it should be stressed that these studies tend to be deep (many assays performed on a single cell sample) rather than broad (testing many cell samples), and there are relatively few metadata captured about the donors, making these data unsuitable for most human disease or exposure studies.

\subsection{Genome-wide assays: the transition from microarrays to massively-parallel sequencing}

Genome-wide study, in essence, involves enriching a fraction of the nucleic acid in the cell and determining where in the genome the nucleic acid came from. Gene expression microarrays represent a well-known paradigm for genome-wide assays. To perform these studies, RNA from the cell is isolated and hybridized to short DNA sequences immobilized on a glass slide. These short DNA sequences are designed to represent each gene in the genome. The RNA is converted to DNA and labeled with fluorescent molecules, so that the presence of a specific gene's RNA

Tab. 2: Large-scale studies studying epigenomic organization

\begin{tabular}{|c|c|c|}
\hline Project & Abbreviation & Web resources \\
\hline ENCyclopedia Of DNA Elements & ENCODE, modENCODE & $\begin{array}{l}\text { http://www.genome.gov/10005107 } \\
\text { http://genome.ucsc.edu/ENCODE/ } \\
\text { http://www.modencode.org/ } \\
\text { http://www.genome.gov/modencode/ }\end{array}$ \\
\hline Roadmap in Epigenomics & & $\begin{array}{l}\text { http://www.roadmapepigenomics.org/ } \\
\text { http://www.epigenomebrowser.org/ } \\
\text { http://www.ncbi.nlm.nih.gov/epigenomics }\end{array}$ \\
\hline The Cancer Genome Atlas & TCGA & $\begin{array}{l}\text { http://www.genome.gov/17516564 } \\
\text { http://cancergenome.nih.gov/ } \\
\text { http://tcga-data.nci.nih.gov/tcga }\end{array}$ \\
\hline International Human Epigenome Consortium & IHEC & http://www.ihec-epigenomes.org/ \\
\hline
\end{tabular}


in the pool isolated from the cell sample will cause the short DNA sequence on the glass slide to acquire a fluorescent signal proportional to the amount of RNA labeled. As the location of the DNA sequences on the slide are pre-defined, scanning the slide to look at relative fluorescence of each DNA sequence location can be converted to a gene expression measure for each gene represented. Chromatin immunoprecipitation (ChIP) can likewise be performed with microarrays, but the starting material differs (immunoprecipitated DNA) and the DNA sequences on the slide also differ (representing regions of interest like gene promoters, for example). Massively-parallel sequencing (MPS) differs by taking the RNA or immunoprecipitated DNA and performing sequencing of the molecules, so that relative enrichment of a certain gene's expression or a chromatin component is measured not by fluorescence intensity but by the relative amount of sequence mapped to a specific gene or location.

Microarray technology matured years before MPS and remains a significant means of investigation of the epigenome and transcriptome. Microarrays have some problems, both technical and financial. From a technical perspective, it was noted that the signal/noise discrimination and dynamic range of signal associated with MPS-based detection greatly exceeds that of identical assays performed using microarrays (Suzuki et al., 2010). From a cost perspective, the price per unit of DNA sequence length is now much less for MPS, but an advantage still retained by microarrays is the ability to study only a limited subset of the genome, which still makes such studies more affordable for microarrays, although the rationale for such limited studies is decreasingly warranted. Furthermore, the data characteristics from MPS-based assays are substantially different from those generated by microarrays - the sequence information allows allelic discrimination, alternative splicing detection, nucleotide resolution DNA methylation studies, and information from as yet unsequenced regions of the genome, making MPS data potentially of even greater value with time.

All MPS technologies to date involve the sequential addition of nucleotides to immobilized target DNA sequences, detecting the events usually through distinctive fluorescence signals and light microscopy but more recently also through hydrogen ion release (http://www.iontorrent.com/). The technologies thus far involve a tradeoff between shorter ( $\leq 200 \mathrm{bp}$ ) sequences but more of them (hundreds of millions) per machine run, or the opposite, longer ( $\geq 500 \mathrm{bp}$ ) but fewer ( $\leq 1$ million) sequences per run. The trend of sequencing technologies is towards continued rapidly growing capacity, with decreasing costs per unit length of DNA sequence, with the oft-stated benchmark goal of a \$ 1,000 genome (Mardis, 2006). The use of MPS is likely to continue to expand beyond even that of today, leading to profound new insights but also the data challenges summarized later in Section 6.

\subsection{The problem of choice in epigenomic assays}

When cells with an identical genome are compared for epigenomic differences following exposure to different toxins, it is apparent even from Table 1 that there are many potential mediators of epigenomic organization, and frequently no indication which one can be assumed to be informative a priori. If any- thing, Table 1 vastly oversimplifies the problem - histone $\mathrm{H} 3$ lysine 9 trimethylation (H3K9me3) is only one of hundreds of post-translational modifications of the canonical core histones (H2A, H2B, H3, and H4) (Bannister and Kouzarides, 2011), before the many histone variants are considered, the positioning of the nucleosomes they assemble, the influence of DNA methylation on the DNA they package, and so on. While our focus in this review is on DNA methylation, it should also be acknowledged that 5-methylcytosine is only one of several cytosine variants now recognized to include 5-hydroxymethylcytosine, 5-formylcytosine, and 5-carboxylcytosine (He et al., 2011). It is therefore extremely difficult to choose the most appropriate assay for a given question, and the cost and cell quantities required for these studies remain sufficiently substantial that a scattershot approach is not an option.

In practice, the choice is often constrained to a focus on DNA methylation studies for a number of reasons. There is generally more familiarity with the assays involved. The sample requirements are usually less onerous (in terms of quantity and preparation) than for RNA or chromatin-focused studies. Furthermore, the assays are demonstrably quantitative, something that has yet to be shown for ChIP followed by MPS (ChIP-seq), an important issue discussed in Section 5.

A significant problem with DNA methylation is that we don't really know how to interpret many of the observed non-promoter changes, and the correlation of DNA methylation with local gene expression changes is far from straightforward. This kind of consideration has kept ChIP-seq of major interest to researchers of human disease, prompting attempts to miniaturize the assay in terms of sample requirements (Adli et al., 2010). Furthermore, as many chromatin components with regulatory associations appear to have redundancy in terms of genomic location and transcriptional function, it appears that it may not be necessary to survey all possible chromatin marks. This hypothesis was tested as part of the ENCODE project (Ernst and Kellis, 2010). They found that certain combinations of chromatin marks or constituents were able to predict regulatory function, and that much of this information could be captured by a subset of the 41 that they tested. This indicates a means by which we may be able to make some informed choices about how to study this large number of regulators when performing epigenomic studies.

\section{Potential effects}

The reason for interest in the role of the epigenome is based on several observations. Firstly, as will be described next (Section 4), there is emerging evidence that sex steroid receptor activity exerts consequential effects by means of some of the epigenomic and transcriptional regulatory processes outlined earlier. Secondly, the field of endocrine disruptor effects is notable for transgenerational consequences - a risk of disease in the unexposed progeny of exposed parents. When this kind of cellular memory event occurs, the obvious question is how such a memory is mediated at the molecular level. The epigenome has properties as described earlier (Section 2) that allow it to be 
considered as a candidate for mediating such long-term memory mechanisms. Thirdly, there are now several studies that link known endocrine active substances and endocrine disruptors to effects on the epigenome (Section 4) that offer more direct evidence for mechanistic associations.

A model for conceptualizing the mechanism by which endocrine disruptors exert their effects might be proposed as follows. Sex steroid hormones have their effects mediated in part through epigenomic and transcriptional regulators. This induces longlasting changes in cellular states that we recognize to be due to normal sex hormone exposure. The long-term maintenance of these new cellular states relies in part upon epigenomic reorganization. The exposure to endocrine disruptors causes similar or distinct effects on cellular states, again mediated in part by epigenomic reorganization. This epigenomic reorganization is not the same as that mediated by endogenous sex steroids, in terms of timing and perhaps the type of epigenomic changes themselves. As demonstrated by several recent publications in animal models (Guerraro-Bosagna et al., 2012; Manikkam et al., 2013; Yeo et al., 2013), there is furthermore a likelihood that the epigenomic changes induced by endocrine disruptors are unusually stable, long-lived, and widespread enough in terms of target cell types that gametes become involved and mediate transgenerational inheritance of these changes, with phenotypic consequences.

This hypothesis is based upon the observations of the next two sections, but it should be stressed that direct evidence, especially in humans, remains only partial (e.g., Kim et al., 2013). As a consequence, while we have sufficient evidence to be concerned about the epigenome mediating pathogenic effects of endocrine disruptors, we lack definitive proof that this is the sole or even major means by which these environmental agents cause human disease consequences.

From a different perspective, in the field of lung cancer, the use of DNA methylation-based biomarkers detectable in, for example, peripheral blood, has emerged as a highly promising method complementing imaging techniques, and these biomarkers are now being actively studied in multiple cancers (Anglim et al., 2008).

\section{Evidence for endocrine disruption being mediated by epigenomic processes}

The relationship between the epigenome and epigenetic regulation has mostly been studied in terms of how genes involved in endocrine signaling are themselves regulated by epigenetic processes such as DNA methylation. This has been reviewed comprehensively (Zhang and Ho, 2011) and allows the data of Table 3 to be presented as a summary of the state of this field.

A more relevant process from the perspective of this review is the effect that endogenous hormones have on the epigenome, so that we can understand how endocrine disruptors may exert their effects. This has also been studied reasonably comprehensively and has been reviewed in detail recently (Zhang and Ho, 2011; LeBaron et al., 2010; Vandegehuchte and Janssen, 2011). A major reason for considering a link between endocrine dis-
Tab. 3: Mammalian endocrine genes regulated by DNA methylation

Adapted from Zhang and Ho, 2011.

\begin{tabular}{|l|l|}
\hline Gene name & Gene symbol \\
\hline P450scc & CYP11A1 \\
\hline 3ß-hydroxysteroid dehydrogenase & HSD3B1/2 \\
\hline 17a-hydroxylase & CYP17A1 \\
\hline $17 \beta$-hydroxylase & HSD17B3 \\
\hline Vitamin D synthesis & CYP27A1/B1 \\
\hline Androgen receptor & AR \\
\hline Estrogen receptor 1 & ESR1 \\
\hline Estrogen receptor 2 & ESR2 \\
\hline Progesterone receptor & PGR \\
\hline Glucocorticoid receptor & NR3C1 \\
\hline Mineralocorticoid receptor & NR3C2 \\
\hline Retinoic acid receptor a & $R A R A$ \\
\hline Retinoic acid receptor $\beta$ & RARB \\
\hline Somatostatin & SST \\
\hline Vasopressin & VAP \\
\hline Melanocyte-stimulating hormone & POMC \\
\hline Secretin & SCT \\
\hline Insulin & INS \\
\hline Leptin & LEP/OB \\
\hline Oxytocin receptor & OXTR \\
\hline Follicle stimulating hormone receptor & FSHR \\
\hline Thyroid stimulating hormone receptor & TSHR \\
\hline Insulin-like growth factor receptors & IGF/IGF2R \\
\hline
\end{tabular}

ruptors and the epigenome is because the action of certain hormones is mediated in part through epigenetic regulators. The molecular mechanisms of endocrine active substances may involve different pathways including interactions with nuclear hormone receptors. Retinoic acid, steroid hormones, calcitriol, and thyroid hormone bind to nuclear receptors within the cell and enter the nucleus to bind as a complex to hormone-responsive elements (Evans, 1988). For example, when the thyroid hormone receptor binds to a response element, the nuclear receptor can do so on its own, in which case it appears to act as a transcriptional repressor, recruiting a multi-protein complex that includes histone deacetylase and SIN3A, whereas if the thyroid hormone receptor binds as a heterodimer with another nuclear receptor, such as retinoid $\mathrm{X}$ receptor, it activates transcription by recruiting the histone acetyltransferases p300/CBP-associated factor (PCAF) and CREB binding protein (CBP) (Zhang 
and Lazar, 2000). Recently, several hundreds of potential transcriptional coregulators that interact directly and indirectly with nuclear receptors have been identified (O'Malley, Qin et al., 2008; Kato and Fujiki, 2011), including fat-soluble ligands like vitamin $\mathrm{A} / \mathrm{D}$, steroid hormone receptors, and peroxisome proliferator-activated receptor gamma (PPAR $\gamma)$, which plays critical roles in metabolism and adipogenesis (Kato and Fujiki, 2011; Sugii and Evans, 2011). Genes that represent specific targets of estrogen receptor alpha have been identified using the chromatin immunoprecipitation approach (Jin et al., 2004; Lin et al., 2007), allowing insight into the downstream effectors of hormonal signaling.

While the regulation of chromatin organization is part of the mechanism for rapid activation or silencing of gene expression, it was described earlier (Section 2.2) how the same mediators can propagate their patterns of activity to daughter cells, allowing them to play a role in mediating cellular memory and permanent changes in cellular states such as differentiation or reprogramming. Why chromatin organization proceeds from a dynamic, reversible state to one that is stable and irreversible is not known, although it is likely that this is a common decision within differentiating cells during development. The epigenetic changes we observe associated with diseases may represent these decisions being made in an abnormal manner. One paradigm of note is intrauterine growth restriction (IUGR), which has been observed in humans and mammalian model organisms to increase the risk of the affected individual to develop obesity and type 2 diabetes mellitus in adulthood, which in the case of humans is decades subsequent to the causative environmental event (Simmons, 2008). When Thompson et al. (2010b) studied a rat model of IUGR and quantified cytosine methylation throughout the genome in beta islet cells from the pancreas of young adult rats, they found a distinct pattern of methylation, discriminating the animals that had undergone IUGR, at loci implicated in glucose metabolism or type 2 diabetes mellitus (Thompson et al., 2010b). It has been proposed that IUGR induces an adaptive response to the scarcity of calories in utero, causing the fetus to reprogram its metabolism during development to hoard calories, which becomes a maladaptive behavior after birth in the presence of adequate nutrition (Gluckman and Hanson, 2004). This represents a paradigm for a remote event causing epigenetic changes that confer a cellular memory of phenotypic consequence. Such a model of epigenetically-mediated changes conferring cellular memory appears to be worth considering for normal endocrine processes and for abnormal hormonal exposures such as those from endocrine disruptors.

There are examples of endocrine active substances for which effects may be mediated by different epigenetic and transcriptional regulatory processes. Bisphenol A (BPA) has been a major focus of investigation for some time, given its broad exposure within the population (Calafat et al., 2008) and the observed effects in animal models on the development of breast and prostate (reviewed in Weng et al., 2010). Until very recently little was published to demonstrate epigenome-wide effects of BPA, with several reports focusing on individual loci (Weng et al., 2010; Bromer et al., 2010; Dolinoy et al., 2007), and two relatively limited genome-wide studies of cytosine methylation in mice, one using the Restriction Landmark Genomic Scanning (RLGS) technique on DNA from mouse forebrain (Yaoi et al., 2008), the other testing prostate tissue using MethylationSensitive Restriction Fingerprinting (MSRF) (Ho et al., 2006), both of which are based on gel electrophoresis and are relatively limited in their genomic comprehensiveness. However, more recently, epigenetic effects throughout the genome have been shown by different groups. Susiarjo et al. (2013) have shown that fetal exposure to BPA at physiologically relevant levels resulted in allelic expression changes of imprinted loci and altered DNA methylation levels at imprinting control regions in mice, in both the embryo and the placenta. Manikkam et al. (2013) have published studies of rats exposed to BPA as a plastics mixture component (with phthalates) at pharmacological doses (not at physiological exposure doses with respect to human exposure and risk assessment). Their results suggest that these endocrine disruptors influence epigenetic transgenerational inheritance of adult onset metabolic and reproductive disease and sperm epimutations.

All these studies show changes in cytosine methylation associated with exposure, some changes occurring at loci that were found to be transcriptionally altered. While these studies have established a foundation for more detailed and sensitive investigation of effects on cytosine methylation, despite the availability of genome-wide methylation assays for some time (Zilberman and Henikoff, 2007), such studies have yet to be published.

Exposure to endocrine disruptors other than bisphenol A has also been found to be associated with epigenetic changes. Gravid rats were exposed to high doses (100-200 mg/kg/day) intraperitoneally of the estrogenic methoxychlor or the androgenic vinclozolin endocrine disruptors between embryonic days 8-15, and spermatogenesis was observed to be abnormal and compromised in several generations of males subsequently in the absence of further exposures (Anway et al., 2005). This transgenerational inheritance of the phenotype suggested an epigenetic mechanism, tested by performing cytosine methylation analyses on testes, again using methylation-sensitive restriction enzymes and a gel electrophoresis detection step. Germ-line epigenetic transgenerational changes in DNA methylation due to an ancestral vinclozolin exposure were further described by the same group (Clement et al., 2010). Changes in methylation were indicated by these studies, and, while sodium bisulfite validation (see Section 7.4) was described, the primary data were not presented in that original study (Anway et al., 2005). While this study has achieved a very high profile and has been extremely provocative, it should be stressed that these findings were subsequently challenged by other groups (reviewed in Renner, 2009). In one subsequent study the authors used an oral administration of vinclozolin to pregnant Wistar rats on days 6-15 post coitum, but failed to find the spermatogenesis phenotype in even the F1 generation animals, concluding that anti-androgenic effects must occur in the later (days 16-20) stage of pregnancy (Schneider et al., 2008). These authors also noted that the no observable adverse effect level (NOAEL) in this study was $>100 \mathrm{mg} / \mathrm{kg}$ /day whereas the World Health Organisation's current acceptable daily intake of vinclozolin 
was $10 \mu \mathrm{g} /(\mathrm{kg}$ body weight $\mathrm{x}$ day), and the original Anway study used 100-200 mg/(kg body weight $x$ day). A second study exactly recapitulated the dosage and route of administration as the original study but also failed to find either a spermatogenesis or a DNA methylation consequence of the vinclozolin exposure (Inawaka et al., 2009). What remains an open question is whether the genetic background of the exposed animals is a critical factor, the original study only seeing this effect in outbred rats (Renner, 2009).

Another study of methoxychlor exposure in rats used a methylation-sensitive restriction enzyme and gel electrophoresis approach with bisulfite PCR or sequencing to assess methylation at a few loci, finding modest changes in methylation levels (Zama and Uzumcu, 2009). Vinclozolin administered to mice allowed testing of the methylation status of several loci undergoing genomic imprinting at which the paternal and maternal chromosomes have different epigenetic organization that results in parent of origin-dependent gene expression (Kacem and Feil, 2009). Bisulfite pyrosequencing at these loci showed very modest degrees of change of cytosine methylation (at most 20\%) associated with exposure (Stouder and Paoloni-Giacobino, 2010). The anti-androgenic di-2-(ethylhexyl) phthalate administered to gravid mice results in testicular function abnormalities in offspring, prompting testing of cytosine methylation for overall cytosine methylation levels using high-performance liquid chromatography and DNA methyltransferase expression studies. A global increase in cytosine methylation of the testicular tissue was observed in the exposed animals, with increases in DNA methyltransferase gene expression and protein levels (Wu et al., 2010a). No locus-specific studies were performed in this project. Another study by this group showed that the same agent was associated with changes in DNA methylation inconsistently through post-natal life (Wu et al., 2010b), adding another level of complexity to the variation observed in epigenetic responses to endocrine disruption.

There has recently been published a report that links exposure to diethylstilbestrol or BPA with increased expression of EZH2, a histone methyltransferase that generates the H3K27me3 repressive modification, when tested in MCF7 breast cancer cells in vitro (Doherty et al., 2010). The same study tested in utero exposure to these agents with the outcome of EZH2 expression in adult mammary gland in a mouse model, finding that both chemicals increased EZH2 protein levels and activity. No locusspecific studies were performed as part of this project, but the next logical step will be to perform H3K27me3 ChIP-seq to see whether this increased EZH2 activity results in new sites of repressive chromatin modifications.

As stressed above (Section 2.2), epigenetic regulatory mechanisms are very numerous, and a focus solely on cytosine methylation is unlikely to be sensitive to all changes occurring in response to endocrine disruptor exposure. In vitro exposure of mammary epithelial cells to diethylstilbestrol was associated with changes in expression of microRNAs (Hsu et al., 2009). With respect to endocrine disruptor exposure, there have yet to be published any studies using genome-wide chromatin immunoprecipitation approaches (such as those testing histone modifications), and while chromatin looping studies have been em- ployed to test how estrogen mediates its effects using cultured cells (Hsu et al., 2009), still no comparable experiments have been described for endocrine active substances and endocrine disrupting chemicals.

\section{Assay methods}

\subsection{Issues to address when considering an epigenomics study}

The studies described above include several approaches towards assessing the role of epigenetic dysregulation. The simplest approach is to perform a candidate gene study, in which one or more genes are chosen based on prior suspicion that they may be involved in the cellular phenotype, and epigenetic studies are performed usually targeting the transcriptional start site (promoter) of the gene. Candidate genes are frequently chosen based on their functional properties or because they were found to change transcriptional levels by using gene expression microarrays. The advantages of this kind of approach are those of time and cost, and usually allow highly quantitative approaches to be performed, at the expense of comprehensiveness and unbiased discovery.

As the comprehensiveness and quantitative capabilities of genome-wide assays improved while costs decreased, the focus has shifted towards what can be described as epigenome-wide association studies. Just as genome-wide association studies look for polymorphisms of DNA sequence that are non-randomly associated with disease phenotypes, epigenome-wide association studies aim to discover loci with changes in epigenetic regulation that occur preferentially in subjects with disease.

Technical approaches used for epigenome-wide association studies currently include those based on microarrays or on MPS (reviewed in Boyle and Furey, 2009), largely superseding the gel-based detection systems described in the prior section. The field of endocrine disruptor biology could benefit from carefully-designed analyses of the epigenome using these updated approaches, especially in human subjects, so it is worth describing some of the challenges involved in performing these studies stringently:

- Study design: The fundamental principles guiding toxicology studies, including, e.g., relevant dose selection, route of administration, and duration of exposure, need to be taken into consideration in the design and interpretation of studies (LeBaron et al., 2010; Goodman et al., 2010).

- Cell type: Epigenetic dysregulation events are believed to be somatic (occurring in a subset of cells in the body/organ) rather than constitutional (occurring in all cells of the body), requiring that the cell type mediating the phenotype be sampled. It is possible that with an exposure event the epigenetic effects may be more widespread, allowing easily-accessible cell types to be sampled as a surrogate, but in general, if there is a disease phenotype affecting a specific organ, it is presumed that cells from that organ should be sampled. This becomes a problem in human studies when the cell type is relatively inaccessible and serves as a justification for the use of rodent or other animal models (Section 7). 
- Cell purity: A further issue has to do with cell purity. Admixture of other cell types presents a challenge because the epigenotypes of histologically-distinctive cell types generally appear to be markedly different. If the proportion or type of cell admixture differs systematically between test and control groups, this may exert enough of an influence to confound the experiment, as the effect sizes (discussed below) may be small. Purifying the cells is not without problems either, as it reduces the sample amount to the point that we may not have sufficient starting material for the epigenomic assay.

- Choice of assay: It has also been stressed that there are numerous possible regulators of the epigenome, which creates the problem of choice referred to earlier in Section 2.6, which may be addressed by using an informative subset of chromatin marks (Ernst and Kellis, 2010). In practice, studies usually focus on cytosine methylation, largely because the samples are easily prepared as DNA compared with the more complex sample preparation required for ChIP-based assays and because of the relative stability of DNA compared with RNA. Cytosine methylation and transcriptional assays are also reasonably quantitative (Suzuki et al., 2010), whereas genomewide ChIP assays have been described to be able to call the presence or absence of peaks but have not been shown to be able to discriminate intermediate values. This is a major concern limiting the use of chromatin immunoprecipitation, as the emerging literature indicates that in non-cancer disease states the differences in methylation at a locus tend to be moderate, our IUGR study finding values differing by as little as 10-20\% (Thompson et al., 2010b), and a recent paper testing liver epigenomes of mice whose fathers were fed with different diets showed a comparable value (Carone et al., 2010). Mechanistically, this is of interest, as cytosine methylation values in an individual cell can be $0 \%$ (neither allele), $100 \%$ (both alleles), or $50 \%$ (one allele methylated), so the only way that there can be a $20 \%$ difference in methylation is when a subset of cells in the population changes its methylation status. This highlights how even modest proportions of contaminating cells can cause problems, as mentioned above, and imposes a requirement for assays to be quantitative as well as comprehensive when performing genome-wide studies. Systems biology meta-analyses approaches can help with the prior refinement and cleaning of such data.

- Powering the study with adequate cohort sizes: If the effect size is limited and the assay has a defined quantitative discriminatory capacity, the cohort sizes required for genuinely comprehensive studies can be modeled. It has been determined that the use of the methyl-sensitive cut counting (MSCC) (Ball et al., 2009) or our HpaII tiny fragment enrichment by ligation-mediated PCR (HELP)-tagging (Suzuki et al., 2010) assays will require 100 subjects in each of the test and control groups to be fully powered (unpublished data). While this represents substantially fewer subjects than generally required for genome-wide association studies, it greatly exceeds the numbers described in the studies of Section 4. When amassing the samples, the cohorts should be chosen with care. It is now recognized that DNA sequence polymorphism can influence chromatin organization, causing it to be polymorphic between individuals (Birney et al., 2010; McDaniell et al., 2010; Kasowski et al., 2010), with similar effects now also observed for sequence variation affecting DNA methylation (Gertz et al., 2011). Cytosine methylation also appears to be influenced by age (Fraga et al., 2005; Thompson et al., 2010a) and gender (Sarter et al., 2005), combining to require that cohorts should be matched in terms of self-reported ethnicity, age, and gender in order to reduce these potential sources of variability (see next paragraph).

- Performing and interpreting comprehensively genome-wide assays: The need for comprehensively genome-wide assays arises because of the emerging evidence that epigenetic regulation of gene expression may not be occurring at predictable locations. There is now a substantial amount of information to suggest that cis-regulatory sequences in the genome are frequently located far from promoters (Heintzman et al., 2007), and that these loci may be preferentially involved in mediating disease states, as found by Thompson et al. in their IUGR study (Thompson et al., 2010b). While microarraybased approaches have had to compromise to focus on predefined loci such as promoters or CpG islands (Hoque et al., 2008; Yamashita et al., 2009), MPS-based approaches have no such constraints and can survey the entire genome. This gives rise to a problem of interpretability - while changes at a promoter are relatively easy to interpret in terms of likely effect on that gene's expression, the non-promoter changes may not even be regulating the nearest gene. It is hoped that the functional annotation of mammalian and model organism genomes being undertaken by the ENCODE and Roadmap in Epigenomics projects will provide some insights that will increase the interpretability of many of these loci, but in the interim many studies will generate significant loci in terms of disease associations without insight into how they may be having mechanistic effects. It is for this reason that concurrent transcriptional studies performed on the same samples offer a means of interpreting how an epigenetic regulatory change may be having functional consequences.

The understanding and interpretation of perceived epigenetic alterations is complicated by an incomplete understanding of the normal state and dynamic variation of the epigenome, which can differ widely between cell and tissue types and stage of development or age (Le Baron et al., 2010). It is thus important to determine the reference epigenome and its range of variability in each model. In the absence of information regarding the control epigenome, any comparison may lead to overestimation or underestimation of the extent of effects of endocrine disruptors, or any other environmental chemicals. For example, Christensen et al. (2009) demonstrated that in normal humans there are changes in the genomic methylation status with age, and whether the location of the target $\mathrm{CpG}$ site is in the $\mathrm{CpG}$ island or outside the island. Loci in $\mathrm{CpG}$ islands gained methylation with age, whereas loci not in $\mathrm{CpG}$ islands lost methylation with age, and this pattern was consistent across tissues. In another study, De Bustos et al. (2009) reported that there exists gross regional difference in methylation between tissues from the same individual. However, profiles of the same tissue from different donors were found 
to be strikingly similar, as well as the profiles of different lobes of the brain. Tissue differences in receptor and enzyme expression are well documented for human and rodent species in the literature. Thus, large epigenetic changes occur in tissues that appear to be normal, and the relationship of these changes to companion genetic changes is of interest to study in the future.

- Cost: An impediment to these genome-wide studies has been cost, especially when the cohort sizes of several hundred individuals are required, and massively-parallel sequencing is employed. What is making these assays more affordable at present is the huge amount of sequence now being generated by MPS, allowing many samples to be combined following barcoding of the individual samples using short sequence tags introduced during library preparation. This multiplexing of samples is driving costs down significantly, to the point that library preparation costs represent the major financial obstacle. With continued increases in sequencing performance, it should be anticipated that these MPS-based assays will become increasingly cost-effective and will allow their widespread adoption for epigenome-wide association studies.

\subsection{Designing an epigenome-wide association study of endocrine disruptors}

The discussions of Section 5 give some guidelines on how we might go about searching for the effects of endocrine disruptors on the epigenome. As a first step there would be a need to determine which cell type to study. The options are more plentiful in animal models, whereas the cell types that represent hormonally-responsive tissues in humans tend to be difficult to acquire with the exception of spermatozoa, which may allow the effects of anti-androgenic endocrine disruptors to be evaluated. A comparable cell type that could be easily sampled in females to test the effect of anti-estrogenic agents is not as obvious. Model organisms such as rodents would not have the same constraints, but have other problems with regard to how they reflect human exposure to toxic substances (Section 7).

The next question is which assay to choose. The effects of steroid hormones on the epigenome were summarized in Section 4 and point to numerous chromatin components (nuclear receptors, ligands, enzyme complexes) and modifications (histone acetylation) that are functionally linked to hormonal signaling and would be prime targets for analysis. The drawback of the genome-wide ChIP-based assays is their non-quantitative properties, which could be reflected by insensitivity of detection of changes at many loci in the genome where subpopulations of cells alter their epigenetic regulatory patterns. Cytosine methylation has been shown in many of the rodent models to be relatively informative, and genome-wide assays designed to test it are reasonably quantitative, making these a first choice system at present. Some of the strengths and limitations of the assays are summarized in Table 4, which focuses on assays based on MPS, and ranks the assays as first choice and alternative.

In addition to the quantitative analysis of the epigenetic regulators themselves, it is valuable to add a transcriptional study of the same cells, so that epigenetic changes can be interpreted in part by presumed effects on gene expression, an especially problematic issue for loci of unknown function.

If a preliminary evaluation of the possibility of epigenomic abnormalities is being sought, there are two types of DNA methylation approaches that could be attempted. An overall global measurement of the amount of 5-methylcytosine can be quantified for the entire genome, or techniques can be applied that look at multiple sites individually genome-wide. Global cytosine methylation can be tested a number of ways, using high-performance liquid chromatography as described earlier (Zhang et al., 2011), testing transposable elements like long or short interspersed nuclear elements (LINEs, SINEs) with bisulfite sequencing (Yang et al., 2004), or performing luminometric methylation analysis (LUMA) (Karimi et al., 2006), to name a few. Genome-wide assays test varying numbers of multiple individual sites, as described earlier (Section 5.1). If a more functional test is required, the viable yellow $\left(\mathrm{A}^{\mathrm{vy}}\right)$ mouse model has been reported by one group to have characteristics that have caused it to be described as an "epigenetic biosensor" (Dolinoy, 2008). The $\mathrm{A}^{\mathrm{vy}}$ allele resulted from the insertion of an intracisternal viral A particle (IAP) upstream of the transcription start site of the Agouti gene, rendering the coat color and the body stature of the Agouti mice dependent of the methylation status of the IAP, ranging from agouti and obese (yellow, low methylation) to pseudoagouti and lean (brown, high methylation) with several degrees of intermediate mottled phenotypes. The IAP transposable element that alters the coat color phenotype in these animals appears to be unusually susceptible to influences that alter the epigenome, such as dietary influences in mice exposed to endocrine active substances (Dolinoy et al., 2007), generating a readout in terms of coat color, which is easily recognizable, and allowing direct analysis of the IAP element in terms of its cytosine methylation as a more quantitative readout (Waterland and Jirtle, 2003). However, as described later in Section 7.3, the evaluation of these viable yellow mice as a model suitable for toxicology studies has not proven to be encouraging and in contrast to the studies by Dolinoy et al. (2007), recently Rosenfeld et al. (2013) showed bisphenol A (BPA) exposure in Agouti mice did not alter coat color distribution.

Cell culture systems represent the mainstay of many of the current studies of endocrine disruptor effects upon the epigenome. Potentially interesting cell culture models include those that allow the in vivo architecture of the cell type to be recapitulated, such as that described for breast epithelial cells (Lee et al., 2007). A problem with cultured (Meissner et al., 2008) and transformed (Wild et al., 2010) cells is that they tend to be substantially modified in terms of their epigenetic organization compared with primary cells, making them poorly comparable with cells sampled from in vivo sources. A further problem is that prolonged culture can change the characteristics of cells, so in vitro systems are going to be maximally useful if the culture conditions are kept identical between conditions being compared and over time.

\subsection{Is the use of model organisms necessary?}

The decision-making process above has the effect of directing us towards the use of model organisms, primarily because of sample acquisition issues, but there are other factors to consider. 
Tab. 4: Molecular epigenomic assay choices in studies of endocrine disruptors

\begin{tabular}{|c|c|c|c|}
\hline Molecular mediator & \multicolumn{2}{|l|}{ Detection method } & Strengths and limitations of method \\
\hline \multicolumn{4}{|l|}{ Primary (recommended) } \\
\hline \multirow[t]{5}{*}{ DNA methylation } & \multirow[t]{2}{*}{$\begin{array}{l}\text { Bisulfite } \\
\text { mutagenesis-based }\end{array}$} & $\begin{array}{l}\text { MethylC-seq } \\
\text { (Lister et al., 2009) }\end{array}$ & $\begin{array}{l}\text { Nucleotide resolution, can interrogate most } \\
\text { cytosines in genome } \\
\text { Expensive }\end{array}$ \\
\hline & & $\begin{array}{l}\text { RRBS } \\
\text { (Meissner et al., 2008) }\end{array}$ & $\begin{array}{l}\text { Nucleotide resolution, relatively inexpensive } \\
\text { Interrogates limited number of cytosines, } \\
\text { focused on CpG-dense regions }\end{array}$ \\
\hline & $\begin{array}{l}\text { Restriction } \\
\text { enzyme-based }\end{array}$ & $\begin{array}{l}\text { HELP-tagging (Suzuki } \\
\text { et al., 2010) MSCC } \\
\text { (Ball et al., 2009) }\end{array}$ & $\begin{array}{l}\text { Relatively inexpensive, tests CpG-dense } \\
\text { and depleted contexts } \\
\text { Interrogates limited number of cytosines }\end{array}$ \\
\hline & Affinity-based & $\begin{array}{l}\text { meDIP-seq } \\
\text { (Down et al., 2008) }\end{array}$ & $\begin{array}{l}\text { Can test throughout genome } \\
\text { Quantitative capacity limited in CpG-depleted } \\
\text { regions, interrogates contiguous groups of CpGs }\end{array}$ \\
\hline & Microarray-based & $\begin{array}{l}\text { 450K Infinium Methylation } \\
\text { BeadChip (Illumina) } \\
\text { (Bibikova et al., 2011) }\end{array}$ & $\begin{array}{l}\text { Inexpensive, design targeted to regions of } \\
\text { presumed function } \\
\text { Interrogates limited number of cytosines, } \\
\text { informativeness depends on design choices }\end{array}$ \\
\hline miRNA & \multicolumn{2}{|l|}{ miRNA-seq } & $\begin{array}{l}\text { Quantitative, can identify previously } \\
\text { undiscovered miRNAs } \\
\text { Library preparation relatively difficult }\end{array}$ \\
\hline RNA & \multicolumn{2}{|c|}{ RNA-seq (Nagalakshmi et al., 2008) } & $\begin{array}{l}\text { Quantitative, can also generate qualitative data } \\
\text { about transcription such as alternative splicing } \\
\text { Data analysis approaches still being optimized }\end{array}$ \\
\hline \multicolumn{4}{|l|}{ Secondary (alternative) } \\
\hline $\begin{array}{l}\text { Chromatin post-translational } \\
\text { modifications, chromatin } \\
\text { constituents }\end{array}$ & \multicolumn{2}{|c|}{ ChIP-seq (Mikkelsen et al., 2007) } & $\begin{array}{l}\text { Tests entire sequenced genome } \\
\text { Resolution limited, not shown to be quantitative }\end{array}$ \\
\hline Chromatin structure & \multicolumn{2}{|c|}{ DNase-seq (Song and Crawford, 2010) } & $\begin{array}{l}\text { Identifies important regulatory regions not located } \\
\text { at annotated promoters } \\
\text { Not shown to be quantitative }\end{array}$ \\
\hline
\end{tabular}

The ability to control and monitor exposures with animal colonies kept in controlled conditions should exceed that possible for human subjects. The potentially confounding effect of genotypic polymorphism can be avoided by using inbred strains, and specific genetic backgrounds can be introduced experimentally. Live animals allow metabolism of agents to other active byproducts that is difficult to achieve using cultured cells. Cells in vitro are also prone to changes in their epigenetic patterns with culture (Allegrucci et al., 2007; Meissner et al., 2008). There are thus numerous advantages to the use of animal models.

One especially advantageous reason for using animal models is the ability to pursue the transgenerational effects of endocrine disruptors (Anway et al., 2005; Anway and Skinner, 2006; Crews et al., 2007; Guerrero-Bosagna and Skinner, 2009). This has already proven interesting in terms of studies of epigenetic organization in testes (Anway et al., 2005), and appears worth pursuing further. It is interesting that cytosine methylation changes have been observed in rat testes sufficiently markedly and reproducibly that they could be detected as a specific effect of vinclozolin (Anway et al., 2005). This is a counter-intuitive result given what is known about cytosine methylation during spermatogenesis and development. The vinclozolin-induced changes in methylation would have to survive two massive waves of demethylation of DNA genome-wide, one occurring early during spermatogenesis (at the fetal stage, following the differentiation of primordial germ cells into early spermatogenic cells), and a second demethylation wave early in embryogenesis that affects the paternally (sperm)-derived haploid genome prior to the maternally-derived contribution, with two phases of remethylation during later spermatogenesis and at the time of implantation (Reik et al., 2001). There is precedent for epigenetic marks surviving these waves of global cytosine methylation 
changes, as imprinted loci appear to retain the memory of their gametic origin despite the early post-fertilization demethylation event (Reik et al., 2001).

So while rodent models have limitations in how they represent human exposures (Stokes, 2004), there remain many rodent models in use to test endocrine disruptors, possibly allowing some short-term experiments to be performed to resolve fundamental questions about whether and how endocrine disruptors influence epigenomic organization in vivo, whilst not increasing animal usage. The goal should be to limit animal use to the unavoidable transgenerational effects studies, which cannot be reproduced or predicted in vitro in cultured cells.

Another type of model organism that has great potential in terms of modeling developmental and epigenetic effects on vertebrates and not only aquatic wildlife, is the zebrafish (Danio rerio) embryo epigenetic toxicity assay. It is important to note that this is not the same test as the Fish Embryo Toxicity Test (FET) in zebrafish, currently validated to test acute lethality in fish (OECD, 2011, 2013). Zebrafish generation time is rapid and the transgenic lines established so far have been shown to be stable through multiple generations (Udvadia and Linney, 2003). Their maintenance is relatively cheap and they are amenable to higher throughput testing. In addition, their use is very much in keeping with the $3 \mathrm{Rs}$, as it is not considered an in vivo test. The zebrafish embryo is establishing itself as a valuable model for toxicity testing, especially for developmental toxicity (McCollum et al., 2011; Augustine-Rauch et al., 2010), including that mediated by the ER (Celeghin et al., 2011). The fish ER has close species similarity to that of mammalian counterparts including human ER (Dang, 2010). Indeed, the US EPA has developed an expert system based upon fish liver ER (Schmieder et al., 2004), and the maternal estrogen receptor $2 \mathrm{a}$ mRNA has been shown to affect embryo transcript contents and larval development (Celeghin et al., 2011). Another receptor, the retinoic acid receptor (RAR), an important heterodimerization partner also involved in the steroidogenic pathway, has been hypothesized to provide an epigenetic mechanism for initiating the diversification of cell types in the developing zebrafish embryo (Linney et al., 2011). In conjunction with microarray analysis, cyp 1a gene expression, and in vitro receptor bioassays, the model has also been used to investigate antagonistic effects on androgen and progesterone receptors (Hawliczek et al., 2012).

Endocrine related and xenobiotic receptors (such as the pregnane $X$ receptor) that have greater species differences would not be such an appropriate mammalian/human model, but the ER would be a good starting point. The vertebrate model organism zebrafish has a reasonably well-studied epigenome that includes DNA methylation as a regulatory process (Wu et al., 2011) (unlike other model organisms such as Drosophila melanogaster in which DNA methylation is at most minimal (Krauss and Reuter, 2011)) and has well-established techniques for chromatin studies (Lindeman et al., 2009). In addition, studies of miRNA functions in the zebrafish also highlight several common principles underlying the functions of animal miRNAs (Mishima, 2012). The use of zebrafish for studies of endocrine active substance, reproductive and developmental screening is now well-established (reviewed in (Krauss and Reuter, 2011)), there are a number of suitable lines (Uddvadia and Linney, 2003) that could be carefully evaluated to select for particular endpoint development, and with a 1.6 billion basepair genome size would require less sequencing for epigenomic assays than a mammalian organism. Zebrafish appear to represent the most suitable model organism available for studies replicating the effects of endocrine active substances and endocrine disruptors on vertebrates and aquatic wildlife and a model that also has great potential for rapid, reliable, and less expensive exploration of the role of epigenetics, aging, senescence, and cancer outcomes in relation to endocrine endpoints, an area that is increasingly important to address in regulatory toxicology, but the current higher level (level 5) in vivo TGs are unable to address for reasons of high cost, extended time, and the humane concerns related to the extension of such tests.

There are clearly well supported reasons for further development in the very near future of the developed zebrafish model that has been successfully applied by many laboratories. It could be developed specifically to address epigenetic endpoints in relation to endocrine activity and phenotypic consequences in the model, to assess the quantitative and predictive capacities for later adverse outcomes. It might also be a useful model to assist in the discussion on the treatment of functional genomics in TGs.

\subsection{What are the potential future advances facilitating new approaches?}

There is reason for optimism regarding our ability to use technology more effectively to gain insights into the epigenomic effects of endocrine disruptors. This is largely based on the phenomenal pace at which MPS is advancing in terms of increasing throughput and reducing costs, exceeding the Moore's law paradigm for the number of transistors that can be placed on an integrated circuit doubling every 2 years: recent experience suggests that sequencing costs per basepair are dropping at a substantially faster rate (Sboner et al., 2011). This is going to make cytosine methylation assays more cost-effective, as mentioned earlier, but also more quantitative, as we can move from limited sampling techniques based on restriction enzymes or reduced genomic representations and instead use shotgun bisulfite sequencing (BS-seq, MethylC-seq; Harris et al., 2010), a substantially more powerful approach. ChIP-based assays will not change in terms of resolution, but it is possible that for transcription factor studies the extra depth of sequencing may allow more comprehensive data to be generated, whereas histone modification studies do not appear to benefit in the same way from greater depth (Rozowsky et al., 2009).

The second area of advance will be in terms of interpretability of findings, highlighted earlier in terms of the non-promoter findings that we will uncover. We are already beginning to understand that transcribed sequences in the genome behave differently in terms of their epigenetic organization compared with non-transcribed sequences, with specific histone modifications (Vakoc et al., 2005) and paradoxically increased cytosine methylation (Ball et al., 2009), requiring that we treat these functionally-defined genomic contexts separately in order to be able to interpret results. A goal for many ongoing studies is to 
be able to define optimal methods for integrating different types of genome-wide data in order to be able to understand epigenomic and transcriptional regulation as a system, including the influences of DNA sequence polymorphism, advances that will greatly facilitate studies addressing specific questions such as the effect of endocrine disruptors upon the epigenome.

\section{Challenges}

These advances do not come without cost. The amount of information generated by these increasingly comprehensive genome-wide assays is becoming the single biggest impediment to gaining insights into the underlying biology (Kahn, 2011). The data need to be managed and secured as a first step, as all digital information can be easily lost through hardware failures unless steps are taken to maintain the system and store copies remotely. This amplifies the magnitude of the datasets, but allows data derived from precious samples to be maintained for subsequent analysis.

The analysis challenge is also substantial (Sboner et al., 2011). Many analyses cannot be performed using standard desktop computing resources because the processing and storage requirements greatly exceed what they can provide. The analyses of these data require multiple steps, for each of which there are competing analytical approaches rather than universallyaccepted standard algorithms. Likewise, quality assessment and control metrics are also heterogeneous and require substantial computational processing to generate meaningful results. The transformation of raw data (microarray fluorescence intensities, MPS DNA sequence reads) into biological information allows very large initial datasets to be shrunk to relatively smaller and more manageable formats, but then the next challenge emerges of making sense of this information. Whether this involves comparing the results from that sample with those in a similar and a comparison cohort, or comparing the results against other genomic annotations, the end result is similar in that there need to be multiple datasets assembled in a single analysis. Again, this represents a computational challenge that is usually addressed by high-performance computing resources, with cloud computing as an emerging alternative or complement.

When integrating datasets, it becomes necessary to remove nuances about the data and transform information into genomic objects (a categorization of epigenetic events by locus). It is not always apparent that the decisions made about how these kinds of transformations are performed reflect relatively subjective decisions, and these may not always be transparent or wellfounded. For example, it was earlier described that increased sequencing of chromatin immunoprecipitation of STAT1 defines increasing numbers of binding sites (Rozowsky et al., 2009), so the definition of the genomic objects of STAT1 binding sites is dependent upon the depth of sequencing performed, which may not be consistent from sample to sample or lab to lab. This issue reinforces the need for not only breadth in epigenomic studies (genome-wide comprehensiveness) but also depth (at specific loci). Another problem has to do with the assumption that different epigenomic events occurring at the same locus must mean that they are present in the same cell. This can only be confidently concluded when all or the vast majority of the cells have the epigenomic event, requiring in turn a quantitative capability for the assay used. If $50 \%$ of the cells are found to have cytosine methylation and $50 \%$ of the cells are found to have a specific histone modification at the same locus, it could be interpreted that both events are occurring in the same cells, but it is also possible that none of the cells have the same event and that they are mutually exclusive. These are challenges inherent to epigenomic data integration that remain largely unsolved and will need to be a focus for the near future.

\section{Conclusions and testing recommendations}

\subsection{Conclusions}

In conclusion, it is possible to state that the evidence thus far is highly suggestive of a role for epigenomic dysregulation mediating the effects of exposures to endocrine disruptors. Mechanistically, it is plausible that the epigenome is responsible for some of the phenotypic consequences of these exposures. These conclusions need to be weighed against the relative weakness of many of the studies performed to date, which have neither been comprehensive nor quantitative, have frequently used in vitro tissue culture systems, or have used mixed cell types from rodent models. There is a major paucity of human subject data at present, another reason for concern.

There are reasons for optimism regarding our abilities to perform well-designed, comprehensive, and sensitive studies to test for epigenomic dysregulation following endocrine disruptor exposure. The absence of standardized assays and analytical approaches coupled with the challenges of managing and analyzing data represent impediments to progress, while we also recognize that there are drawbacks to in vitro cell culture systems, animal models, and human studies, making no system ideal for these studies, although rodent models offer a lot of advantages in the short-term.

\subsection{Testing recommendations}

In defining some testing recommendations, a number of influences are taken into account. Firstly, the need to minimize animal use to the greatest extent possible, so cell culture systems that may be useful are included. Secondly, the need to be guided by prior experience in this field, including dosage regimens for in vitro and in vivo systems. Therefore, a varied range of studies of endocrine disruptor use with epigenetic consequences has been summarized; these studies provided details that could be used to guide formal regulatory pre-validation and validation study designs. Only one of the studies (Hsu et al., 2009) included epigenomic assays, Doherty et al. (2010) studied EZH2 expression, Chaturvedi et al. (2010) studied expression levels of a few genes, whilst the Hsu reports $(2009,2010)$ studied miRNA and more general transcription, methylation, and chromatin studies. The in vitro cell systems are listed in Table 5 and in vivo assays in Table 6.

Note that only one animal study from Table 6 in which epigenetic assays were performed also included pharmacokinetic 
Tab. 5: Published cell culture systems that could potentially be used for testing the epigenetic effects of endocrine disruptors

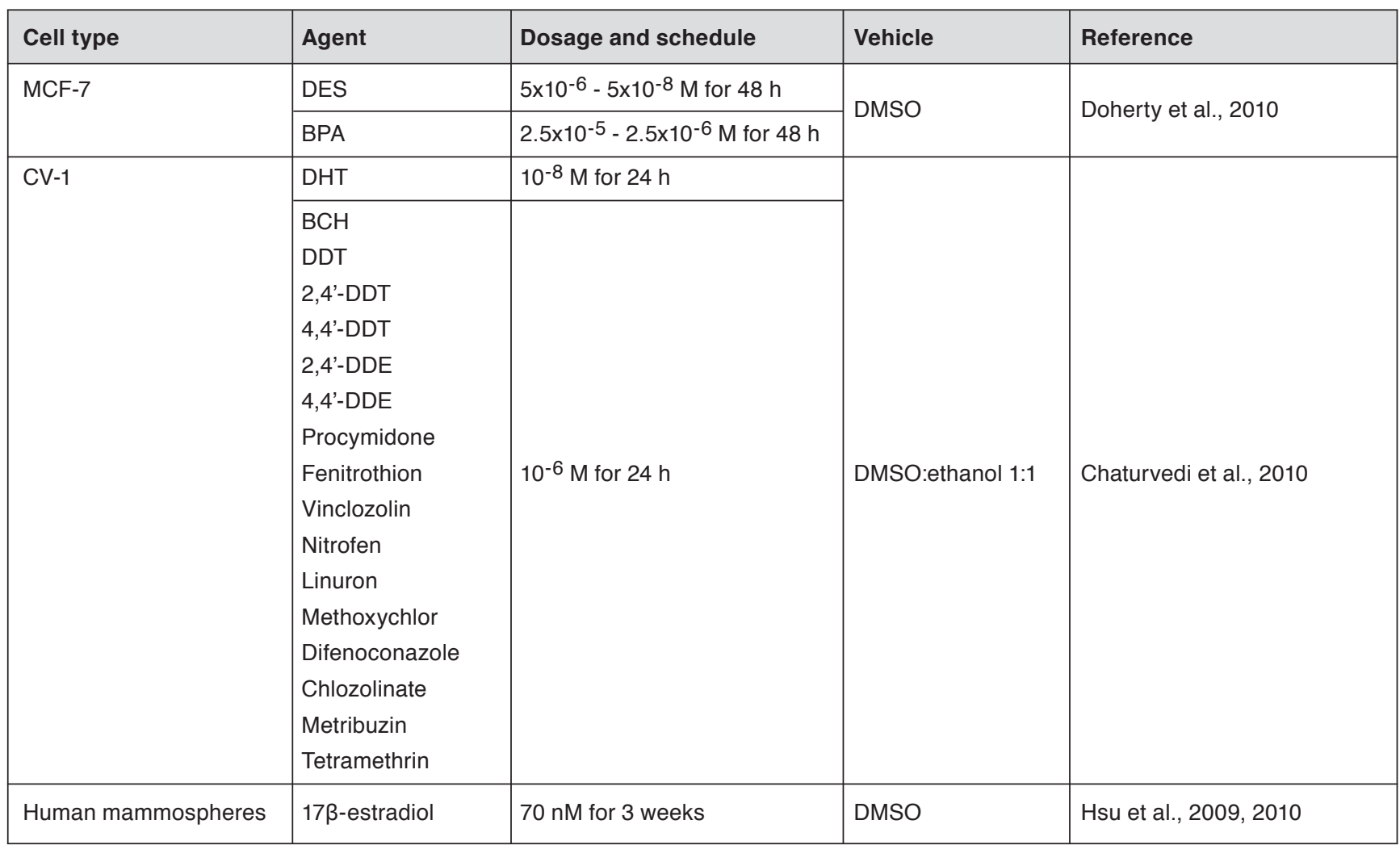

$\mathrm{BCH}$, brominated flame retardant; BPA, bisphenol A; CV-1, a cell line derived from an adult male Cercopithecus aethiops monkey kidney; DDE, dichlorodiphenyldichloroethylene; DDT, dichlorodiphenyltrichloroethane; DES, diethylstilbestrol; DHT, dihydrotestosterone; DMSO, dimethylsulfoxide; MCF7, Michigan Cancer Foundation-7 breast cancer cell line

Tab. 6: Published animal systems that could potentially be used for testing the epigenetic effects of endocrine active substances

\begin{tabular}{|c|c|c|c|c|c|c|c|}
\hline $\begin{array}{l}\text { Animal } \\
\text { species and } \\
\text { strain }\end{array}$ & Agent & $\begin{array}{l}\text { Dosage and } \\
\text { schedule }\end{array}$ & Vehicle & $\begin{array}{l}\text { Tissue } \\
\text { sampled, } \\
\text { timing }\end{array}$ & Test outcome & $\begin{array}{l}\text { Comments related to } \\
\text { potential EAS- } \\
\text { epigenetics test } \\
\text { development }\end{array}$ & Reference \\
\hline $\begin{array}{l}\text { Rat (Sprague- } \\
\text { Dawley) }\end{array}$ & DEX & $\begin{array}{l}50 \mathrm{mg} / \mathrm{kg} \text { per } \\
\text { dose PO on } \\
\text { PND 25, } 60 \text {, } \\
\text { or } 65\end{array}$ & Corn oil & $\begin{array}{l}\text { Liver } \\
\text { Up to } \\
4 \text { days } \\
\text { following } \\
\text { exposure }\end{array}$ & $\begin{array}{l}\text { ChIP of PXR at } \\
\text { Cyp3a1 promoter }\end{array}$ & $\begin{array}{l}\text { Major species differences } \\
\text { between rat/human PXR and } \\
\text { CYP metabolism of DEX. } \\
\text { Model more appropriate for } \\
\text { drug interaction and species } \\
\text { differences in metabolism than } \\
\text { EAS. }\end{array}$ & $\begin{array}{l}\text { Ronis et al., } \\
2011\end{array}$ \\
\hline $\begin{array}{l}\text { Mouse (Swiss } \\
\text { albino) }\end{array}$ & DDT & $\begin{array}{l}50 \mathrm{mg} / \mathrm{kg} / \mathrm{day} \\
\text { in olive } \\
\text { oil } x 7 \text { days on } \\
\text { PND } 28-42 \text {, } \\
\text { male }\end{array}$ & Olive oil & $\begin{array}{l}\text { Liver } \\
\text { Testis } \\
1 \text { day } \\
\text { following } \\
\text { last } \\
\text { exposure }\end{array}$ & $\begin{array}{l}\text { AR and PXR } \\
\text { transcription } \\
\text { and subcellular } \\
\text { dynamics }\end{array}$ & & $\begin{array}{l}\text { Chaturvedi } \\
\text { et al., } 2010\end{array}$ \\
\hline
\end{tabular}




\begin{tabular}{|c|c|c|c|c|c|c|c|}
\hline $\begin{array}{l}\text { Animal } \\
\text { species and } \\
\text { strain }\end{array}$ & Agent & $\begin{array}{l}\text { Dosage and } \\
\text { schedule }\end{array}$ & Vehicle & $\begin{array}{l}\text { Tissue } \\
\text { sampled, } \\
\text { timing }\end{array}$ & Test outcome & $\begin{array}{l}\text { Comments related to } \\
\text { potential EAS- } \\
\text { epigenetics test } \\
\text { development }\end{array}$ & Reference \\
\hline Rat (Fisher) & $\begin{array}{l}\text { Methoxy } \\
\text { chlor } \\
\text { Vinclozolin }\end{array}$ & $\begin{array}{l}100 \text { or } \\
200 \mathrm{mg} / \\
\mathrm{kg} / \mathrm{day} \\
\text { IP on GD 8-15 }\end{array}$ & DMSO & $\begin{array}{l}\text { Testis } \\
\text { Sperm } \\
\text { PND 60 } \\
\text { (F1-F4) }\end{array}$ & $\begin{array}{l}\text { Qualitative } \\
\text { assessment of } \\
\text { spermatogenesis, } \\
\text { DNA methylation } \\
\text { studies of sperm }\end{array}$ & & $\begin{array}{l}\text { Anway et } \\
\text { al., } 2005\end{array}$ \\
\hline Mouse (a/a) & BPA & $\begin{array}{l}50 \mathrm{mg} / \mathrm{kg} / \\
\text { day PO } 2 \\
\text { weeks pre- } \\
\text { mating, then } \\
\text { throughout } \\
\text { gestation and } \\
\text { lactation, } \\
\text { adult female }\end{array}$ & None & $\begin{array}{l}\text { Tail } \\
\text { Brain } \\
\text { Liver } \\
\text { Kidney } \\
\text { PND } 22\end{array}$ & $\begin{array}{l}\text { DNA methylation } \\
\text { studies }\end{array}$ & $\begin{array}{l}\text { This model is not highly } \\
\text { recommended due to the } \\
\text { excessive numbers of animals } \\
\text { needed for such studies and } \\
\text { the qualitative nature of the } \\
\text { data obtained. }\end{array}$ & $\begin{array}{l}\text { Dolinoy et } \\
\text { al., } 2007\end{array}$ \\
\hline Mouse (a/a) & Genistein & $\begin{array}{l}250 \mathrm{mg} / \\
\mathrm{kg} / \mathrm{day}, \\
2 \text { weeks pre- } \\
\text { mating then } \\
\text { throughout } \\
\text { gestation and } \\
\text { lactation, } \\
\text { adult female }\end{array}$ & $\begin{array}{l}\text { Corn oil } \\
\text { and } \\
\text { soy oil }\end{array}$ & $\begin{array}{l}\text { Tail } \\
\text { Brain } \\
\text { Liver } \\
\text { Kidney } \\
\text { PND } 22\end{array}$ & $\begin{array}{l}\text { DNA methylation } \\
\text { studies }\end{array}$ & $\begin{array}{l}\text { This model is not highly } \\
\text { recommended due to the } \\
\text { excessive numbers of animals } \\
\text { needed for such studies and } \\
\text { the qualitative nature of the } \\
\text { data obtained. }\end{array}$ & $\begin{array}{l}\text { Dolinoy et } \\
\text { al., } 2006\end{array}$ \\
\hline \multirow[t]{2}{*}{$\begin{array}{l}\text { Rat (Sprague- } \\
\text { Dawley) }\end{array}$} & BPA & \multirow[t]{2}{*}{$\begin{array}{l}10 \mu \mathrm{g} / \mathrm{kg} \\
0.1 \text { and } 2500 \\
\mu \mathrm{g} / \mathrm{kg} \mathrm{SQ} \text { on } \\
\text { PND } 1,3,5\end{array}$} & \multirow[t]{2}{*}{ Corn oil } & \multirow[t]{2}{*}{$\begin{array}{l}\text { Prostate } \\
28 \text { weeks }\end{array}$} & $\begin{array}{l}\text { Histopathology } \\
\text { and DNA } \\
\text { methylation } \\
\text { studies }\end{array}$ & & $\begin{array}{l}\text { Ho et al., } \\
2006\end{array}$ \\
\hline & $\begin{array}{l}17 \beta- \\
\text { estradiol } \\
\text { 3-benzoate }\end{array}$ & & & & $\begin{array}{l}\text { Histopathology } \\
\text { and DNA } \\
\text { methylation } \\
\text { studies in relation } \\
\text { to early life } \\
\text { reprogramming } \\
\text { and prostate } \\
\text { carcinogenesis } \\
\text { during adulthood. }\end{array}$ & $\begin{array}{l}\text { This follow-up model } \\
\text { from the same laboratory } \\
\text { identified different patterns } \\
\text { in gene methylation changes } \\
\text { throughout life, e.g., an early } \\
\text { and permanent epigenetic } \\
\text { mark (NSbp 1), and of neonatal } \\
\text { exposure to estradiol/BPA }\end{array}$ & $\begin{array}{l}\text { Tang et al., } \\
2012\end{array}$ \\
\hline Mouse (FVB) & Vinclozolin & $\begin{array}{l}50 \mathrm{mg} / \mathrm{kg} / \\
\text { day IP } \\
\text { GD } 10-18\end{array}$ & Corn oil & $\begin{array}{l}\text { Motile } \\
\text { sperm Tail } \\
\text { Liver } \\
\text { Skeletal } \\
\text { muscle } \\
\text { PND 60 } \\
\text { (F1 - F2) }\end{array}$ & $\begin{array}{l}\text { Sperm counts } \\
\text { and DNA } \\
\text { methylation } \\
\text { studies }\end{array}$ & & $\begin{array}{l}\text { Stouder and } \\
\text { Paoloni- } \\
\text { Giacobino, } \\
2010\end{array}$ \\
\hline $\begin{array}{l}\text { Mouse } \\
\text { (Kunming) }\end{array}$ & $\begin{array}{l}\text { Di-2-(ethyl- } \\
\text { hexyl) } \\
\text { phthalate }\end{array}$ & $\begin{array}{l}500 \mathrm{mg} / \mathrm{kg} / \\
\text { day } \mathrm{PO} \\
\text { GD } 12.5-19\end{array}$ & Corn oil & GD19 & $\begin{array}{l}\text { Global DNA } \\
\text { methylation } \\
\text { quantification, } \\
\text { expression levels } \\
\text { of DNMTs }\end{array}$ & & $\begin{array}{l}\text { Wu et al., } \\
2010 a\end{array}$ \\
\hline \multirow[t]{2}{*}{ Mouse (CD-1) } & DES & $\begin{array}{l}5 \mathrm{mg} / \mathrm{kg} / \mathrm{day} \\
\text { IP } \\
\text { GD 9-26 }\end{array}$ & \multirow[t]{2}{*}{$\begin{array}{l}\text { Sesame } \\
\text { oil }\end{array}$} & \multirow[t]{2}{*}{$\begin{array}{l}\text { Mammary } \\
6 \text { weeks }\end{array}$} & \multirow[t]{2}{*}{$\begin{array}{l}\text { EZH2 expression } \\
\text { and function } \\
\text { studies }\end{array}$} & & \multirow[t]{2}{*}{$\begin{array}{l}\text { Doherty et } \\
\text { al., } 2010\end{array}$} \\
\hline & BPA & $\begin{array}{l}10 \mu \mathrm{g} / \mathrm{kg} / \text { day } \\
\text { IP } \\
\text { GD 9-26 }\end{array}$ & & & & & \\
\hline
\end{tabular}

AR, androgen receptor; BPA, bisphenol A; ChIP, chromatin immunoprecipitation; DES, diethylstilbestrol; DEX, dexamethasone; DNMT, DNA methyltransferase; EZH2, enhancer of zeste homologue 2; GD, gestational day; IP, intraperitoneally; PND, postnatal day; PO, per os, by mouth; PXR, pregnane $\mathrm{X}$ receptor; $\mathrm{SQ}$, subcutaneously 
Tab. 7: OECD Test Guidelines that could potentially be adapted for epigenomic studies of effects of endocrine disruptors

\begin{tabular}{|c|c|c|}
\hline Type of study & Test Guidelines (TG) & Description \\
\hline Acute Toxicity Study & - TG 236 & $\begin{array}{l}\text { - (Zebra) Fish Embryo Toxicity Study } \\
\text { - Zebrafish embryo epigenetic toxicity assay }\end{array}$ \\
\hline General chronic exposure studies & $\begin{array}{l}\text { - TG } 451 \\
\text { - TG } 452 \\
\text { - TG } 453\end{array}$ & $\begin{array}{l}\text { - Carcinogenicity Studies } \\
\text { - Chronic Toxicity Studies } \\
\text { - Combined Chronic Toxicity/Carcinogenicity Studies }\end{array}$ \\
\hline Post-mitotic cell studies & - TG 424 & - Neurotoxicity Study in Rodents \\
\hline Prenatal effects & $\begin{array}{l}\text { - TG } 414 \\
\text { - TG } 426\end{array}$ & $\begin{array}{l}\text { - Prenatal Development Toxicity Study } \\
\text { - Developmental Neurotoxicity Study }\end{array}$ \\
\hline Reproductive effects & $\begin{array}{l}\text { - TGs } 415,416 \\
\text { - TG } 421 \\
\text { - TG } 422 \\
\text { - TG } 443\end{array}$ & $\begin{array}{l}\text { - One- and Two-Generation Reproduction Toxicity } \\
\text { - Reproduction/Developmental Toxicity Screening Test } \\
\text { - Combined Repeated Dose Toxicity Study with the } \\
\text { Reproduction/ Developmental Toxicity Screening Test } \\
\text { - Extended One-Generation Reproductive Toxicity Study }\end{array}$ \\
\hline $\begin{array}{l}\text { Potentially relevant tests to be } \\
\text { used in combination }\end{array}$ & - TG 473 & - In vitro Mammalian Chromosome Aberration Test \\
\hline
\end{tabular}

The italicized test is not in the OECD TG workplan as yet.

analyses, Doherty et al. (2010) measuring BPA levels in mice on gestational day 13 , at $1,6,12$, and 18 hours after the last dose of BPA. They found peak levels of BPA of $24.7 \mathrm{ng} / \mathrm{ml}$ at 1 hour following administration, when control (vehicle-only) levels were $1.7 \mathrm{ng} / \mathrm{ml}$. At 6 hours the BPA levels were $3 \mathrm{ng} / \mathrm{ml}$, and subsequently indistinguishable from background. It will be necessary to incorporate information from other studies that do not have epigenetic components for their more detailed pharmacokinetic data, such as the recent report from Prins's group. (Prins et al., 2011) testing BPA doses in Sprague-Dawley rats.

Recommendations for testing, based on existing test systems used by the OECD, are listed by broad category in Table 7. A point worth mentioning is that the essence of epigenomic dysregulation is the potential for longer-term memory of exposure, making a delay between exposure and effect testing desirable, in contrast with many other outcomes that may be sought. Of these, only the extended one-generation reproductive toxicity study (TG 443) is currently designed to include both epigenetic and endocrine endpoints, making it the most immediately suitable for adaptation. The zebrafish embryo epigenetic toxicity assay is the most relevant alternative test model with which to proceed for regulatory hazard and risk assessment development (Section 5.2).

\subsubsection{Choice of test}

A modification of TG 473 (In vitro Mammalian Chromosome Aberration Test) that left out the use of metaphase-arresting substances in exposed cells could allow these cells to be used to screen for epigenetic effects, without having to introduce a new cell type for study. Section 7.3 also describes how human embryonic stem cells (hES) may represent a new tool for in vitro cultured cell studies of chemical toxicity, although efforts to explore this do not appear to have been successful so far, for regulatory use, and rodent and zebra fish embryo models have been demonstrated to be more reliable and accurate in test chemical predictions (for teratogenicity; Augustine-Rauch et al., 2010), and thus more amenable to regulatory requirement needs. Where definitive animal tests are necessary, there are three tests that appear suitable for testing epigenetic effects of exposures throughout the body, which could be performed by harvesting material from animals sacrificed as part of ongoing studies without the need to test further animals. TGs 451 (Carcinogenicity Studies), 452 (Chronic Toxicity Studies), and 453 (Combined Chronic Toxicity/Carcinogenicity Studies) all involve animal exposures by different routes, with a necropsy subsequent to the exposure schedule that would allow the opportunity for tissue harvesting. Correlative histopathology and clinical chemistry studies will allow some epigenetic findings to be interpreted. The cell types to be tested should meet the criteria of Section 5 in terms of purity and phenotypic relevance, in the current case choosing cells that are hormonally responsive. TG 424 (Neurotoxicity Study in Rodents) focuses more specifically on the central nervous system, composed mostly of post-mitotic cells, with studies of brain function to complement histopathology and epigenetic studies. Prenatal effects are potentially studied using TG 414 (Prenatal Development Toxicity Study), which involves the exposure to animals of agents during pregnancy and testing the fetus at term for abnormalities, while TG 426 (Developmental Neurotoxicity Study) allows the offspring to be born and to develop, testing 
specifically for neurological consequences. Tissues harvested at both time points could shed light on epigenetic effects of agents used for exposure.

It would be premature to draw any firm conclusions about the application of the threshold (TTC) approach in relation to substances that may have endocrine activity, although there are very few examples of where this has been done for specific endocrine mechanisms (such as ER alpha mediated thresholds in the aquatic environment), and thus this would also currently apply for an epigenetic threshold mechanism in relation to the endocrine system. Regarding thresholds for epigenetic changes, whether the effects of endocrine disruptors (or any other chemical) are manifested in a binary fashion beyond a certain threshold exposure dose, such as, an open or closed state of the chromatin, hypermethylated or hypomethylated CpGs, or whether epigenomic changes might be dose-dependent is also unclear. However, because DNA methylation can be quantified, DNA hypermethylation or hypomethylation of specific target loci can be used to determine whether epigenomic changes show a dose-dependent response. Thus inducing an epigenetic change by increasing the dose beyond relevant real-life scenario exposure levels (as is seen in the case of vinclozolin studies), may not be the best way to draw conclusions about the potential, real-life, epigenetic effects of endocrine disruptors. There is an identified research need to examine epigenomic alterations and transgenerational effects at very low doses, and whether there is any significance.

One concern about endocrine disruptors is that they may have lingering transgenerational effects mediated by the epigenome. A genuinely transgenerational study requires looking as far as the F3 generation (Skinner, 2008). Current test systems only proceed to the F2 generation, so available mammalian test systems are not going to be definitive in testing for transgenerational effects, and will at best generate indicative, preliminary insights. There exist five tests that may allow such preliminary testing for transgenerational effects mediated by epigenetic dysregulation. TGs 415 and 416 (One- and Two-Generation Reproduction Toxicity), TG 421 (Reproduction/Developmental Toxicity Screening Test), and TG 422 (Combined Repeated Dose Toxicity Study with the Reproduction/Developmental Toxicity Screening Test) all involve exposures followed by assessments of reproductive capacity and/or gonadal histology and function. Of these, the TGs 415 and 416 (One- and Two-Generation Reproduction Toxicity) could both allow multiple tissues to be sampled in offspring of parents exposed to the agent of interest, allowing screening for inherited epimutations in these samples. The new Extended One-Generation Reproductive Toxicity Study (TG 443) also has the potential for the necropsy and neurological studies of the tests described in the previous paragraph, and therefore represents a recommended mainstay for animal testing.

\subsubsection{Specific examples of tests}

Cultured cells will be exposed to chemicals to look for toxicological effects on those cells. Epigenomic studies can use the same test parameters (e.g., dose levels) as those that led to toxicological effects in previous studies, with the caveat that the cells should be assessed for viability, as the presence of dead cells in substantial proportions $(>10 \%)$ in the material assayed could cause artifacts, requiring that viable cells be sorted from the dead cells (e.g., using propidium iodide and flow sorting). The cells will need to be fixed with formaldehyde soon after harvesting if chromatin immunoprecipitation is a planned assay, whereas flash freezing and/or the use of RNAlater (Qiagen) can be used to preserve RNA for later expression studies. Flash freezing is sufficient for preservation of DNA for later cytosine methylation analyses. Samples should be stored at $-20^{\circ} \mathrm{C}$ until use.

Epigenomic assays should initially be performed on at least 10 exposed and 10 non-exposed samples, allowing the presence and degree of epigenomic dysregulation to be assessed, so allowing a decision to be made about whether to (a) proceed with the number of further samples defined by the effect sizes and power calculations estimated on the basis of the first groups, (b) perform single-locus validation on loci appearing to be non-randomly altering their epigenetic regulatory patterns in response to chemical exposure, expanding the numbers beyond the initial limited groups.

Should animal systems be required, the exposures should be those that (a) reproducibly induce the associated phenotypic effect in that animal and, ideally, (b) are comparable to any exposure described for humans. It may be necessary to perform pharmacokinetic profiling in the animal system if human exposures are described in terms of measured total and free concentrations of the chemicals in blood or other body samples. Human and rodent BPA pharmacokinetic and serum levels have recently been shown to be similar using both oral and subcutaneous dosing. Free and total BPA at $\mathrm{C}_{\max }$ were 1.77 and $2.0 \mathrm{ng} / \mathrm{ml}$, respectively, following injection and 0.3 and $1.0 \mathrm{ng} / \mathrm{ml}$, respectively, following oral exposure. The $\mathrm{AUC}_{0-2}$ for free and total BPA was 4.1-fold and 1.8-fold greater, respectively, in subcutaneous versus oral delivery. While exposure route affected BPA metabolism, internal dosimetry following subcutaneous injection of $10 \mu \mathrm{g} \mathrm{BPA} / \mathrm{kg} \mathrm{BW}$ is similar to BPA levels observed in humans (Prins et al., 2011). Serum levels of BPA that were measured in cohorts of women with and without histories of recurrent miscarriages, revealed that the former group had mean \pm SD values of $2.6 \pm 5.2 \mathrm{ng} / \mathrm{ml}$ with the controls averaging $0.8 \pm 0.4 \mathrm{ng} / \mathrm{ml}$ (Sugiura-Ogasawara et al., 2005), levels comparable to those that can be generated in mice (Doherty et al., 2010). A BPA study could therefore be guided by prior studies (Doherty et al., 2010) with a dosage schedule of $5 \mathrm{mg} / \mathrm{kg} /$ day intraperitoneally in sesame oil administered to gravid mice between gestational days 9-16, testing cells from offspring at 6 weeks of age.

Cell samples should be collected from the phenotypicallyaffected organ(s) to a reasonable degree of purity, as discussed in Section 5.1. For example, motile sperm collected from mice following vinclozolin exposure (Stouder and Paoloni-Giacobino, 2010) represents an homogenous cell population manifesting the phenotypic effect of the chemical, meeting these criteria. It is probably worthwhile sampling more cell types than are obviously necessary at the outset, as this will allow future studies to be performed without the need to use more experimental animals. 


\subsection{Potential new test systems}

While there are many ways that current OECD test systems can be adapted quite easily for analysis of epigenetic dysregulation, it is worth considering a couple more possibilities that are often suggested. The viable yellow $\left(\mathrm{A}^{\mathrm{vy}}\right)$ mouse model was described earlier (Section 6), allowing screening for effects of exposures during pregnancy by the use of coat color or cytosine methylation analysis of the IAP element (Waterland and Jirtle, 2003). However, in contrast to these studies, recently Rosenfeld et al. (2013) showed BPA exposure in Agouti mice did not alter coat color distribution, but there was a suggestion that Agouti A ${ }^{\mathrm{vy}}$ conceptuses may possess a "thrifty" genotype and be at a competitive advantage in certain uterine environments that can predispose the offspring to metabolic syndrome when food is plentiful. This may therefore not be such a useful mouse resource. Another perhaps more useful mouse model to consider is the Axin 1 fused (Axin $1^{\mathrm{Fu}}$ ) mouse strain. These mice also have a visible phenotype that is responsive to influences perturbing the epigenome (Waterland et al., 2006). Mice have been described that variegate transgenes expressed in peripheral blood, allowing genetic screens to look for mediators of the variegation phenotype (Ashe et al., 2008), a system that may be amenable to testing for epigenetic regulatory polymorphism. In each case the animals could be used as a means of screening for epigenetic disturbances, without the need for genome-wide molecular assays at the outset. Set against this is the lack of insight into how sensitive each mouse model or strain is in reporting diverse influences on the epigenome, making it uncertain how valuable these experimental animals are for screening purposes. Furthermore, a study specifically designed to assess whether the $\mathrm{A}^{\mathrm{vy}}$ mouse model was suitable for testing in toxicology studies demonstrated that the hundreds of animals needed for such studies and the qualitative nature of the data obtained makes it an impractical choice (Rasoulpour et al., 2011).

The other major avenue involves the use of embryonic stem (ES) cells that are in vitro-differentiated to the germ cell lineage, which is now technically feasible (Rohwedel et al., 2001), allowing a cell culture model that may be able to recapitulate the effects of in vivo exposures. This is potentially a very interesting means of generating human cell types that are normally very difficult to obtain, and is not restricted to the use of germ cells, as many lineages can now be generated from pluripotent ES and induced pluripotent stem (iPS) cells of different cell types should be potentially informative. Both human and mouse ES cells can be used in this way, mouse being generally easier to grow and manipulate than human ES cells. The Embryonic Stem cell-based Novel Alternative Testing Strategies (ESNATS) initiative in Europe (http:// www.esnats.eu/) represents a formal attempt to use ES cells for toxicity testing, potentially providing a new system that can be widely adopted and allows more limited use of animal systems. In practice, however, it is the mouse ES systems that will be more feasible and reliable to utilize for regulatory testing purposes. The use of these systems participates in the recent progress in understanding the underlying molecular mechanisms of epigenetics in embryonic stem cells as compared to those of differentiated cells and has unveiled key regulatory roles of epigenetic marks driving cellular pluripotency, differentiation, and self-renewal/proliferation (see Ang et al., 2011; Barrero et al., 2010).

\subsection{Molecular validation of tests}

The epigenomic tests of greatest current value are those that study cytosine methylation, for reasons described earlier, and will represent the cornerstone of epigenomic testing for some time to come. Other valuable tests will include transcriptional profiling (of RNA and of small processed RNAs) and chromatin immunoprecipitation-based techniques.

The validation of each requires a different type of assay. For cytosine methylation, the gold standard is the chemical mutagenesis of DNA with sodium bisulfite to create uracil where there existed an unmethylated cytosine in the original DNA, whereas methylcytosine remains unconverted. Quantitative single locus studies of PCR amplicons that compare the proportion of cytosine to thymine (to which the uracil is converted during PCR) measures the methylation at that locus. Platforms such as Sequenom's MassArray (Ehrich et al., 2005) or Qiagen's Pyrosequencer (Fakhrai-Rad et al., 2002) can perform this measurement highly quantitatively.

For transcriptional profiling and for chromatin immunoprecipitation, validation is performed by quantitative PCR using primers directed at specific loci. The relative enrichment of one locus compared with another is compared with that predicted from the genome-wide approach as a means of quantitative validation.

These validation steps are appropriate for testing how individual experiments perform, but a second avenue of validation is to test how variable are the individual experiments themselves. Validation should seek to capture not only experimental variability but also the variability of the biological system. The former can be assessed by performing replicate experiments repeatedly on the same sample, while the latter is best assessed by testing multiple separate samples. The goal is to determine how much of an influence experimental variability has on biological variability, and how much influence biological variability has on the test system, combining to generate a measure of confidence in the results as a whole. As added measures of stringency, reproducibility in independent laboratories at different times is also essential for confidence in the results.

Any identification of epigenomic effects with endogenous hormones (dihydrotestosterone, 17 $\beta$-estradiol) as used previously (Chaturvedi et al., 2010; Ho et al., 2006) would provide a very useful benchmark for candidate endocrine disruptors, which can be substantially less potent in inducing cellular proliferation but comparable in other respects such as inducing calcium influx when compared with endogenous hormones (vom Saal and Hughes, 2005).

What is not yet possible is the ability to influence epigenetic regulation at specific loci to make them reflect those observed associated with the phenotype of interest. For example, it is impossible to turn a locus from an unmethylated to a methylated state, although global methylation can be driven in different directions by drugs (Claus and Lubbert, 2003; Pogribny et al., 
2008) or diet (Niculescu and Zeisel, 2002). Functional validation remains an elusive component of current studies of epigenomic dysregulation.

\section{Recommendations}

It is clear that epigenetic modulations underlie critical developmental processes and contribute to determining adult phenotype. Moreover, phenotypic alterations due to exposure to environmental insults during sensitive periods of development are mediated through alterations in epigenetic programming in affected tissues. Consequently, monitoring such marks in response to toxicant exposure may in future provide a valuable tool for predicting adverse outcomes. Systems biology and bioinformatics approaches for pathway analyses will further improve the knowledge on the links between the epigenome and phenotype, and provide guidance for in vitro test development batteries.

However, there remains a need for further fundamental research to allow a more robust basis for OECD TG recommendations. In particular, there is a need to improve knowledge on the links between the modulation of the epigenome and associated phenotypes. In addition, although there is evidence to suggest that epigenomic dysregulation might mediate effects of exposure to endocrine disruptors, it is uncertain as to whether these changes are truly predictive of adverse outcome(s). Results obtained in the OECD transgenerational assays will not be able to indicate transgenerational effects, as they only evaluate up to the F2 generation, however they can indicate epigenomic effects, i.e., directly indicate whether the observed effects occur via an epigenetic mechanism of action. Adverse effects observed in these studies could be used to inform future tests specifically designed to investigate the mechanism of action. Follow up studies should include both an epigenetic, as well as a genomic component to differentiate the contribution of potentially compensatory mechanisms.
While it may be premature to initiate OECD TG activity, because of the rapid scientific development in the epigenetic field, it is important to monitor progress and take up the challenge to develop better approaches for evaluating the strength of evidence, together with improved methods for evaluation of the evidence for endocrine disruption (WHO/UNEP, 2013). Exploiting new methodological approaches is necessary to meet this challenge, and it is by further developing epigenetic methodology, for which proof of concept is currently under development, that the hazard and risk assessment of endocrine disruptors can be better and more transparently addressed.

It is recommended that, in the near future, an expert group be convened, in coordination with other relevant expert OECD groups, to identify promising models to be developed into TG(s).

In addition to research exploring the link between epigenetic effects and adverse outcomes, the following issues could be considered to ensure that ongoing research supports future TG development. Promising models, such as those present in Table 8 , need to be further explored or developed. Table 8 indicates how these tests may start to be integrated, and identifies some preliminary reference chemicals to assist with the development of such a battery of tests.

Additionally, the identification of prototype chemicals is necessary to determine the sensitivity and specificity of model systems. To understand the linkage between chemically-induced epigenetic modifications and phenotypic outcomes, data on epigenetic endpoints could be obtained from samples collected from in vivo models, particularly those adequately sensitive to ED-induced effects across various life stages. This information will be useful to refine testing designs for in vitro and in vivo test models. An important goal would be to develop in vitro and short-term assays for the assessment of chemically-induced epigenetic changes predictive of adverse outcomes, taking into account the role of nuclear receptors as transcriptional factors in the mechanism of action of endocrine active substances.

Tab. 8: Updated OECD endocrine disruptor testing conceptual framework combined with potential epigenetic tests and preliminary reference chemicals

\begin{tabular}{|c|c|c|c|}
\hline Level & $\begin{array}{l}\text { Mammalian and non } \\
\text { mammalian toxicology }\end{array}$ & Epigenetic test information & $\begin{array}{l}\text { Potential prototype chemicals to } \\
\text { determine the sensitivity and } \\
\text { specificity of model systems }\end{array}$ \\
\hline $\begin{array}{l}\text { Level } 1 \\
\text { Existing Data and } \\
\text { Non-Test Information }\end{array}$ & $\begin{array}{l}\text { Physical \& chemical } \\
\text { properties, e.g., MW reactivity, } \\
\text { volatility, biodegradability }\end{array}$ & $\begin{array}{l}\text { Epigenetic literature review } \\
\text { information }\end{array}$ & \\
\hline 1 & $\begin{array}{l}\text { All available (eco)toxicological } \\
\text { data from standardized or } \\
\text { non-standardized tests. }\end{array}$ & $\begin{array}{l}\text { Epigenetic literature review } \\
\text { information }\end{array}$ & \\
\hline 1 & $\begin{array}{l}\text { Read across, chemical } \\
\text { categories, QSARs and other } \\
\text { in silico predictions, and } \\
\text { ADME model predictions }\end{array}$ & $\begin{array}{l}\text { e.g., literature-derived information } \\
\text { about DNA methylation, RNA and } \\
\text { miRNA expression studies, and } \\
\text { chromatin structure and modification } \\
\text { data, with analyses to identify bio- } \\
\text { markers for detection of compounds } \\
\text { with epigenetic ED activity }\end{array}$ & \\
\hline
\end{tabular}




\begin{tabular}{|c|c|c|c|}
\hline Level & $\begin{array}{l}\text { Mammalian and non } \\
\text { mammalian toxicology }\end{array}$ & Epigenetic test information & $\begin{array}{l}\text { Potential prototype chemicals to } \\
\text { determine the sensitivity and } \\
\text { specificity of model systems }\end{array}$ \\
\hline $\begin{array}{l}\text { Level } 2 \\
\text { In vitro assays providing } \\
\text { data about selected } \\
\text { endocrine } \\
\text { mechanism(s)/pathways }\end{array}$ & $\begin{array}{l}\text { Estrogen or androgen receptor } \\
\text { binding affinity (Draft TG for } \\
\text { ER binding expected end } \\
2013 \text {, early 2014) }\end{array}$ & $\begin{array}{l}\text { Combine with TG } 473 \text { but leave out } \\
\text { the use of metaphase-arresting } \\
\text { substances in exposed cells. This } \\
\text { could then be used to screen for } \\
\text { epigenetic effects. }\end{array}$ & $\begin{array}{l}\text { Positive for ER: } \\
17 \beta \text { estradiol } \\
\text { Positive for ER and epigenetic effects: } \\
\text { DES, BPA, genistein, equol (includes } \\
\text { metabolism) } \\
\text { Positives: for AR: } \\
\text { Testosterone } \\
\text { Positives: for AR and epigenetic } \\
\text { effects: } \\
\text { Vinclozolin, flutamide, hydro- } \\
\text { xyflutamide (metabolite) } \\
\text { Negatives: for ER effects } \\
\text { Corticosterone, spironolactone, } \\
\text { atrazine, linuron }\end{array}$ \\
\hline 2 & $\begin{array}{l}\text { Estrogen receptor trans- } \\
\text { criptional activation } \\
\text { (TG 455, TG 457) }\end{array}$ & $\begin{array}{l}\text { Relevant endpoints: } \\
\text { - DNA modifications (cytosine } \\
\text { methylation) } \\
\text { - miRNA and RNA expression studies } \\
\text { - Studies of chromatin components } \\
\text { and structure }\end{array}$ & $\begin{array}{l}\text { Positives: for ED and epigenetic } \\
\text { effects } \\
\text { DES, BPA, genistein, equol (includes } \\
\text { metabolism), OH Tamoxifen }\end{array}$ \\
\hline 2 & $\begin{array}{l}\text { Androgen or thyroid trans- } \\
\text { criptional activation (if/when } \\
\text { TGs are available) }\end{array}$ & $\begin{array}{l}\text { Relevant endpoints: } \\
\text { - DNA modifications (cytosine } \\
\text { methylation) } \\
\text { - miRNA and RNA expression studies } \\
\text { - Studies of chromatin components } \\
\text { and structure }\end{array}$ & $\begin{array}{l}\text { Positives: for ER and epigenetic } \\
\text { effects: DES, BPA, genistein, equol } \\
\text { (includes metabolism) } \\
\text { Positives: for AR and epigenetic } \\
\text { effects: Vinclozolin, flutamide, } \\
\text { hydroxyflutamide (metabolite) }\end{array}$ \\
\hline 2 & $\begin{array}{l}\text { Steroidogenesis in vitro } \\
\text { (TG 456) }\end{array}$ & $\begin{array}{l}\text { Relevant endpoints: } \\
\text { - DNA modifications (cytosine } \\
\text { methylation) } \\
\text { - miRNA and RNA expression studies } \\
\text { - Studies of chromatin components } \\
\text { and structure } \\
\text { - Multivariate/systems analysis to } \\
\text { identify key regulatory factors } \\
\text { mediating variability of steroido- } \\
\text { genesis on a chemical specific basis }\end{array}$ & $\begin{array}{l}\text { Positives for ED: } \\
\text { Prochloraz, forskolin, atrazine, } \\
\text { aminoglutethimide, bisphenol A, DBP } \\
\text { Negative for ED: } \\
\text { human chorionic gonadotropin (HCG) }\end{array}$ \\
\hline 2 & $\begin{array}{l}\text { MCF-7 cell proliferation } \\
\text { assays (ER ant-/agonist) }\end{array}$ & $\begin{array}{l}\text { Relevant endpoints: } \\
\text { - DNA modifications (cytosine } \\
\text { methylation) } \\
\text { - miRNA and RNA expression studies } \\
\text { - Studies of chromatin components } \\
\text { and structure } \\
\text { - Multivariate/systems analysis to } \\
\text { identify what is mediating variability } \\
\text { of cell proliferation }\end{array}$ & $\begin{array}{l}\text { As for ER/transactivation assays, } \\
\text { plus substances acting through } \\
\text { estrogenic but not receptor pathways } \\
\text { (e.g., through non genomic pathways } \\
\text { and SULTs, (OP), DBP } \\
\text { (dibutylphthalates)). }\end{array}$ \\
\hline 2 & $\begin{array}{l}\text { Fish Embryo Toxicity Test } \\
\text { (TG 236) } \\
\text { Potential adaptation to Zebra- } \\
\text { fish embryo epigenetic assay }\end{array}$ & $\begin{array}{l}\text { Relevant endpoints: } \\
\text { - DNA modifications (cytosine } \\
\text { methylation) } \\
\text { - Studies of chromatin components } \\
\text { and structure }\end{array}$ & \\
\hline
\end{tabular}




\begin{tabular}{|c|c|c|c|}
\hline Level & $\begin{array}{l}\text { Mammalian and non } \\
\text { mammalian toxicology }\end{array}$ & Epigenetic test information & $\begin{array}{l}\text { Potential prototype chemicals to } \\
\text { determine the sensitivity and } \\
\text { specificity of model systems }\end{array}$ \\
\hline 2 & $\begin{array}{l}\text { Possible additional examples } \\
\text { 1. Casa assay } \\
\text { (sperm cell toxicant) } \\
\text { 2. Comet assay } \\
\text { (sperm cell mutagen) } \\
\text { 3. Sertoli cell assay } \\
\text { 4. Leydig cell assay (cross ref } \\
\text { with steroidogenesis assay } \\
\text { TG 456) } \\
\text { 5. Oogenesis, follicular culture } \\
\text { 6. Mouse embryonic stem } \\
\text { D3 cell assay (Kleinstreuer } \\
\text { et al., 2011) } \\
\text { 7. Human embryonic stem cells } \\
\text { 8. Rat whole embryo culture } \\
\text { toxicity assay }\end{array}$ & $\begin{array}{l}\text { Relevant endpoints: } \\
\text { - DNA modifications } \\
\text { (cytosine methylation) } \\
\text { - miRNA and RNA expression studies } \\
\text { - Luminometric methylation analysis } \\
\text { (LUMA) for global methylation } \\
\text { analyses } \\
\text { - Studies of chromatin components } \\
\text { and structure } \\
\text { - Multivariate/systems analysis to } \\
\text { elucidate relevant regulation factors } \\
\text { and pathways }\end{array}$ & $\begin{array}{l}\text { 1. Valproic acid, DES, lindane, } \\
\text { carbenazim, nonylphenol } \\
\text { 2. DES, lindane, carbenazim, } \\
\text { nonylphenol di-2-(ethylhexyl) } \\
\text { phthalate, DBP } \\
\text { 3. BPA and as above } \\
\text { 4. DES, carbenazim, nonylphenol, } \\
\text { taxol, ketoconazole } \\
\text { 5. DES, genistein, carbenazim, } \\
\text { nonylphenol, ketoconazole }\end{array}$ \\
\hline $\begin{array}{l}\text { Level } 3 \\
\text { In vivo assays } \\
\text { providing data about } \\
\text { selected endocrine } \\
\text { mechanism(s) / } \\
\text { pathway(s) }^{1}\end{array}$ & Uterotrophic assay (TG 440) & $\begin{array}{l}\text { Less relevant endpoint: } \\
\text { correlation changes in uterine } \\
\text { tissue with molecular changes } \\
\text { (epigenomic assays) }\end{array}$ & \\
\hline 3 & Hershberger assay (TG 441) & $\begin{array}{l}\text { No end organ present, not } \\
\text { appropriate for testing }\end{array}$ & \\
\hline $\begin{array}{l}\text { Level } 4 \\
\text { In vivo assays providing } \\
\text { data on adverse effects } \\
\text { on endocrine relevant } \\
\text { endpoints } 2\end{array}$ & $\begin{array}{l}\text { Repeated dose 28-day } \\
\text { study (TG 407) } \\
\text { TG } 422\end{array}$ & $\begin{array}{l}\text { Relevant endpoints: } \\
\text { - DNA modifications (cytosine } \\
\text { methylation) } \\
\text { - miRNA and RNA expression studies } \\
\text { - Studies of chromatin components } \\
\text { and structure } \\
\text { e.g., Testicular histopathology } \\
\text { combined with epigenomic dys- } \\
\text { regulation assays. } \\
\text { With tissues of interest available, } \\
\text { need to consider issues of sample } \\
\text { collection and preservation, cellular } \\
\text { heterogeneity, etc., as discussed } \\
\text { in text. }\end{array}$ & \\
\hline 4 & $\begin{array}{l}\text { Repeated dose 90-day study } \\
\text { (TG 408) }\end{array}$ & & \\
\hline 4 & 1-generation assay (TG 415) & $\begin{array}{l}\text { 1. Combination with TGs } 451 \\
\text { (Carcinogenicity Studies), } \\
452 \text { (Chronic Toxicity Studies), } \\
\text { and } 453 \text { (Combined Chronic } \\
\text { Toxicity/Carcinogenicity Studies) } \\
\text { with focus on hormonally- } \\
\text { responsive tissues: combination } \\
\text { with epigenomic assays. } \\
\text { 2. The rat model of IUGR and } \\
\text { quantified cytosine methylation } \\
\text { throughout the genome in beta } \\
\text { islet cells from the pancreas of } \\
\text { young adult rats, results indicate } \\
\text { a distinct pattern of methylation } \\
\text { discriminating the animals that } \\
\text { had undergone IUGR, at loci } \\
\text { implicated in glucose metabolism } \\
\text { or type } 2 \text { diabetes mellitus } \\
\text { (Thompson et al., 2010b). BPA } \\
\text { studies all showed changes in } \\
\text { cytosine methylation associated } \\
\text { with exposure, some changes } \\
\text { occurring at loci that were found to } \\
\text { be transcriptionally altered. }\end{array}$ & $\begin{array}{l}\text { Valproic acid (male: reduction of } \\
\text { spermatogenesis, testicular } \\
\text { atrophy, degeneration of seminiferous } \\
\text { tubules; female: polycystic ovaries, } \\
\text { high serum testosterone, and } \\
\text { menstrual disorders; teratogenic). }\end{array}$ \\
\hline
\end{tabular}




\begin{tabular}{|c|c|c|c|}
\hline Level & $\begin{array}{l}\text { Mammalian and non } \\
\text { mammalian toxicology }\end{array}$ & Epigenetic test information & $\begin{array}{l}\text { Potential prototype chemicals to } \\
\text { determine the sensitivity and } \\
\text { specificity of model systems }\end{array}$ \\
\hline 4 & $\begin{array}{l}\text { Prenatal development toxicity } \\
\text { study (TG 414) }\end{array}$ & & \\
\hline 4 & $\begin{array}{l}\text { Chronic toxicity and } \\
\text { carcinogenicity studies } \\
\text { (TG 451-3) }\end{array}$ & & \\
\hline 4 & $\begin{array}{l}\text { Reproductive screening test } \\
\text { (TG } 421 \text { if enhanced) }\end{array}$ & $\begin{array}{l}\text { Eestrus cycles, follicle counts, } \\
\text { oocyte maturation, ovarian integrity; } \\
\text { spermatogenesis combination with } \\
\text { epigenomic assays, toxicogenomics } \\
\text { and multivariate data analyses }\end{array}$ & \\
\hline 4 & $\begin{array}{l}\text { Combined } 28 \text { day/reproductive } \\
\text { screening assay } \\
\text { (TG } 422 \text { if enhanced) } \\
\text { Developmental neurotoxicity } \\
\text { (TG 426) }\end{array}$ & $\begin{array}{l}\text { Prenatal effects are potentially studied } \\
\text { using TG } 414 \text { (Prenatal Development } \\
\text { Toxicity Study) which involves the } \\
\text { exposure to animals to agents during } \\
\text { pregnancy, testing the fetus at term for } \\
\text { abnormalities, while TG } 426 \\
\text { (Developmental Neurotoxicity Study) } \\
\text { allows the offspring to be born and to } \\
\text { develop, testing specifically for neuro- } \\
\text { logical consequences. Tissues } \\
\text { harvested at both time points could } \\
\text { shed light on epigenetic effects of } \\
\text { agents used for exposure. }\end{array}$ & \\
\hline $\begin{array}{l}\text { Level } 5 \\
\text { In vivo assays providing } \\
\text { more comprehensive } \\
\text { data on adverse effects } \\
\text { on endocrine relevant } \\
\text { endpoints over more } \\
\text { extensive parts } \\
\text { of the life cycle of } \\
\text { the organism }\end{array}$ & $\begin{array}{l}\text { Extended one-generation } \\
\text { reproductive toxicity study } \\
\text { (TG 443) }\end{array}$ & $\begin{array}{l}\text { Necropsy and neurological studies } \\
\text { of the tests for TG } 426,414,424 \text {, etc. }\end{array}$ & $\begin{array}{l}\text { Valproic acid, DES, lindane, } \\
\text { carbenazim, nonylphenol, BPA, DBP, } \\
\text { DEHP, taxol, ketoconazole, genistein, } \\
\text { vinclozolin, methoxychlor }\end{array}$ \\
\hline 5 & $\begin{array}{l}\text { 2-generation assay } \\
\text { (TG } 416 \text { most recent update) }\end{array}$ & $\begin{array}{l}\text { TG (416) could allow multiple tissues } \\
\text { to be sampled in offspring of parents } \\
\text { exposed to the agent of interest, } \\
\text { allowing screening for inherited } \\
\text { epimutations. }\end{array}$ & $\begin{array}{l}\text { Valproic acid, DES, lindane, } \\
\text { carbenazim, nonylphenol, BPA, taxol, } \\
\text { ketoconazole, genistein, vinclozolin, } \\
\text { methoxychlor, DBP, DEHP. }\end{array}$ \\
\hline
\end{tabular}

Italicized tests are not in OECD TG workplan as yet.

\section{References}

Adli, M., Zhu, J., and Bernstein, B. E. (2010). Genome-wide chromatin maps derived from limited numbers of hematopoietic progenitors. Nat Methods 7, 615-618.

Allegrucci, C., Wu, Y.Z., Thurston, A., et al. (2007). Restriction landmark genome scanning identifies culture-induced DNA methylation instability in the human embryonic stem cell epigenome. Hum Mol Genet 16, 1253-1268.

Alleman, M., Sidorenko, L., McGinnis, K., et al. (2006). An RNA-dependent RNA polymerase is required for paramutation in maize. Nature 442, 295-298.

Ang, Y. S., Gaspar-Maia, A., Lemischka, I. R., et al. (2011). Stem cells and reprogramming: breaking the epigenetic barrier? Trends Pharmacol Sci 32, 394-401.

Anglim, P. P., Alonzo, T. A., and Laird-Offringa, I. A. (2008).
DNA methylation-based biomarkers for early detection of non-small cell lung cancer: an update. Mol Cancer 7, 81 .

Anway, M. D., Cupp, A. S., Uzumcu, M., et al. (2005). Epigenetic transgenerational actions of endocrine disruptors and male fertility. Science 308, 1466-1469.

Anway, M. D. and Skinner, M. K. (2006). Epigenetic transgenerational actions of endocrine disruptors. Endocrinology 147 , S43-49.

Ashe, A., Morgan, D. K., Whitelaw, N. C., et al. (2008). A genome-wide screen for modifiers of transgene variegation identifies genes with critical roles in development. Genome Biol 9, R182.

Augustine-Rauch, K., Zhang, C. X., and Panzica-Kelly, J. M. (2010). In vitro developmental toxicology assays: A review of the state of the science of rodent and zebrafish whole embryo 
culture and embryonic stem cell assays. Birth Defects Res $C$ Embryo Today 90, 87-98.

Ball, M. P., Li, J. B., Gao, Y., et al. (2009). Targeted and genome-scale strategies reveal gene-body methylation signatures in human cells. Nat Biotechnol 27, 361-368.

Bannister, A. J. and Kouzarides, T. (2011). Regulation of chromatin by histone modifications. Cell Res 21, 381-395.

Barrero, M. J., Boue, S., and Izpisua Belmonte, J. C. (2010). Epigenetic mechanisms that regulate cell identity. Cell Stem Cell 7, 565-570.

Beckerman, R. and Prives, C. (2010). Transcriptional regulation by p53. Cold Spring Harbor Perspect Biol 2, a000935.

Beiter, T., Reich, E., Williams, R. W., et al. (2009). Antisense transcription: a critical look in both directions. Cell Mol Life Sci 66, 94-112.

Bernstein, E., Muratore-Schroeder, T. L., Diaz, R. L., et al. (2008). A phosphorylated subpopulation of the histone variant macroH2A1 is excluded from the inactive $\mathrm{X}$ chromosome and enriched during mitosis. Proc Natl Acad Sci U S A 105, 1533-1538.

Bibikova, M., Barnes, B., Tsan, C., et al. (2011). High density DNA methylation array with single $\mathrm{CpG}$ site resolution. $G e$ nomics 98, 288-295.

Birney, E., Lieb, J. D., Furey, T. S., et al. (2010). Allele-specific and heritable chromatin signatures in humans. Hum Mol Genet 19, R204-209.

Boyle, A. P. and Furey, T. S. (2009). High-resolution mapping studies of chromatin and gene regulatory elements. Epigenomics 1, 319-329.

Bromer, J. G., Zhou, Y., Taylor, M. B., et al. (2010). Bisphenol-A exposure in utero leads to epigenetic alterations in the developmental programming of uterine estrogen response. FASEB J 24, 2273-2280.

Calafat, A. M., Ye, X., Wong, L. Y., et al. (2008). Exposure of the U.S. population to bisphenol A and 4-tertiary-octylphenol: 2003-2004. Environ Health Perspect 116, 39-44.

Carone, B. R., Fauquier, L., Habib, N., et al. (2010). Paternally induced transgenerational environmental reprogramming of metabolic gene expression in mammals. Cell 143, 10841096.

Celeghin, A., Benato, F., Pikulkaew, S., et al. (2011). The knockdown of the maternal estrogen receptor $2 \mathrm{a}$ (esr2a) mRNA affects embryo transcript contents and larval development in zebrafish. Gen Comp Endocrinol 172, 120-129.

Chandler, V. L. (2007). Paramutation: from maize to mice. Cell $128,641-645$.

Chaturvedi, N. K., Kumar, S., Negi, S., et al. (2010). Endocrine disruptors provoke differential modulatory responses on androgen receptor and pregnane and xenobiotic receptor: potential implications in metabolic disorders. Mol Cell Biochem 345, 291-308.

Claus, R. and Lubbert, M. (2003). Epigenetic targets in hematopoietic malignancies. Oncogene 22, 6489-6496.

Clement, T. M., Savenkova, M. I., Settles, M., et al. (2010). Alterations in the developing testis transcriptome following embryonic vinclozolin exposure. Reprod Toxicol 30, 353-364.

Crews, D., Gore, A. C., Hsu, T. S., et al. (2007). Transgenera- tional epigenetic imprints on mate preference. Proc Natl Acad Sci U S A 104, 5942-5946.

Christensen, B. C., Houseman, E. A., Marsit, C. J., et al. (2009). Aging and environmental exposures alter tissue-specific DNA methylation dependent upon $\mathrm{CpG}$ island context. PLoS Genet $5, \mathrm{e} 1000602$.

Dang, Z. (2010). Comparison of relative binding affinities to fish and mammalian estrogen receptors: the regulatory implications. Toxicol Letters 192, 298-315.

De Bustos, C., Ramos, E., Young, J. M., et al. (2009). Tissuespecific variation in DNA methylation levels along human chromosome 1. Epigenetics Chromatin 2, 7.

Delaval, K. and Feil, R. (2004). Epigenetic regulation of mammalian genomic imprinting. Curr Opin Genet Dev 14, 188195.

Doherty, L. F., Bromer, J. G., Zhou, Y., et al. (2010). In utero exposure to diethylstilbestrol (DES) or Bisphenol-A (BPA) increases EZH2 expression in the mammary gland: An epigenetic mechanism linking endocrine disruptors to breast cancer. Horm Cancer 1, 146-155.

Dolinoy, D. C., Weidman, J. R., Waterland, R. A., et al. (2006). Maternal genistein alters coat color and protects Avy mouse offspring from obesity by modifying the fetal epigenome. Environ Health Perspect 114, 567-572.

Dolinoy, D. C., Huang, D., and Jirtle, R. L. (2007). Maternal nutrient supplementation counteracts bisphenol A-induced DNA hypomethylation in early development. Proc Natl Acad Sci U $S$ A 104, 13056-13061.

Dolinoy, D. C. (2008). The agouti mouse model: an epigenetic biosensor for nutritional and environmental alterations on the fetal epigenome. Nutr Rev 66, Suppl 1, S7-11.

Down, T. A., Rakyan, V. K., Turner, D. J., et al. (2008). A Bayesian deconvolution strategy for immunoprecipitation-based DNA methylome analysis. Nat Biotechnol 26, 779-785.

Ehrich, M., Nelson, M. R., Stanssens, P., et al. (2005). Quantitative high-throughput analysis of DNA methylation patterns by base-specific cleavage and mass spectrometry. Proc Natl Acad Sci U S A 102, 15785-15790.

Ernst, J. and Kellis, M. (2010). Discovery and characterization of chromatin states for systematic annotation of the human genome. Nat Biotechnol 28, 817-825.

Evans, R. M. (1988). The steroid and thyroid hormone receptor superfamily. Science 240, 889-895.

Fakhrai-Rad, H., Pourmand, N., and Ronaghi, M. (2002). Pyrosequencing: an accurate detection platform for single nucleotide polymorphisms. Hum Mutat 19, 479-485.

Fraga, M. F., Ballestar, E., Paz, M. F., et al. (2005). Epigenetic differences arise during the lifetime of monozygotic twins. Proc Natl Acad Sci U S A 102, 10604-10609.

Francis, N. J., Follmer, N. E., Simon, M. D., et al. (2009). Polycomb proteins remain bound to chromatin and DNA during DNA replication in vitro. Cell 137, 110-122.

Gertz, J., Varley, K. E., Reddy, T. E., et al. (2011). Analysis of DNA methylation in a three-generation family reveals widespread genetic influence on epigenetic regulation. PLoS Genetics 7, e1002228.

Gluckman, P. D. and Hanson, M. A. (2004). Maternal constraint 
of fetal growth and its consequences. Semin Fetal Neonatal Med 9, 419-425.

Goodman, J. I., Augustine, K. A., Cunnningham, M. L., et al. (2010). What do we need to know prior to thinking about incorporating an epigenetic evaluation into safety assessments? Toxicol Sci 116, 375-381.

Goyal, R., Reinhardt, R., and Jeltsch, A. (2006). Accuracy of DNA methylation pattern preservation by the Dnmt1 methyltransferase. Nucleic Acids Res 34, 1182-1188.

Grafodatskaya, D., Choufani, S., Ferreira, J. C., et al. (2010). EBV transformation and cell culturing destabilizes DNA methylation in human lymphoblastoid cell lines. Genomics 95, 73-83.

Guerrero-Bosagna, C. M. and Skinner, M. K. (2009). Epigenetic transgenerational effects of endocrine disruptors on male reproduction. Semin Reprod Med 27, 403-408.

Guerrero-Bosagna, C., Covert, T. R., Haque, M. M., et al. (2012). Epigenetic transgenerational inheritance of vinclozolin induced mouse adult onset disease and associated sperm epigenome biomarkers. Reprod Toxicol 34, 694-707.

Hansen, R. S., Wijmenga, C., Luo, P., et al. (1999). The DNMT3B DNA methyltransferase gene is mutated in the ICF immunodeficiency syndrome. Proc Natl Acad Sci U S A 96, 14412-14417.

Harris, R. A., Wang, T., Coarfa, C., et al. (2010). Comparison of sequencing-based methods to profile DNA methylation and identification of monoallelic epigenetic modifications. Nat Biotechnol 28, 1097-1105.

Hartley, P. D. and Madhani, H. D. (2009). Mechanisms that specify promoter nucleosome location and identity. Cell 137, 445-458.

Hawliczek, A., Nota, B., Cenijn, P., et al. (2012). Developmental toxicity and endocrine disrupting potency of 4-azapyrene, benzo[b]fluorene and retene in the zebrafish Danio rerio. Reprod Toxicol 33, 213-223.

He, Y. F., Li, B. Z., Li, Z., et al. (2011). Tet-mediated formation of 5-carboxylcytosine and its excision by TDG in mammalian DNA. Science 333, 1303-1307.

Heintzman, N. D., Stuart, R. K., Hon, G., et al. (2007). Distinct and predictive chromatin signatures of transcriptional promoters and enhancers in the human genome. Nat Genet 39, 311-318.

Hiragami-Hamada, K., Xie, S. Q., Saveliev, A., et al. (2009). The molecular basis for stability of heterochromatin-mediated silencing in mammals. Epigenetics Chromatin 2, 14.

Ho, S. M., Tang, W. Y., Belmonte de Frausto, J., et al. (2006). Developmental exposure to estradiol and bisphenol A increases susceptibility to prostate carcinogenesis and epigenetically regulates phosphodiesterase type 4 variant 4. Cancer Res 66, 5624-5632.

Hoque, M. O., Kim, M. S., Ostrow, K. L., et al. (2008). Genome-wide promoter analysis uncovers portions of the cancer methylome. Cancer Res 68, 2661-2670.

Hsu, P. Y., Deatherage, D. E., Rodriguez, B.A., et al . (2009). Xenoestrogen-induced epigenetic repression of microRNA-9-3 in breast epithelial cells. Cancer Res 69, 5936-5945.
Hsu, P. Y., Hsu, H. K., Singer, G. A., et al. (2010). Estrogenmediated epigenetic repression of large chromosomal regions through DNA looping. Genome Res 20, 733-744.

Inawaka, K., Kawabe, M., Takahashi, S., et al. (2009). Maternal exposure to anti-androgenic compounds, vinclozolin, flutamide and procymidone, has no effects on spermatogenesis and DNA methylation in male rats of subsequent generations. Toxicol Appl Pharmacol 237, 178-187.

Jia, D., Jurkowska, R. Z., Zhang, X., et al. (2007). Structure of Dnmt3a bound to Dnmt3L suggests a model for de novo DNA methylation. Nature 449, 248-251.

Jin, V. X., Leu, Y. W., Liyanarachchi, S., et al. (2004). Identifying estrogen receptor alpha target genes using integrated computational genomics and chromatin immunoprecipitation microarray. Nucleic Acids Res 32, 6627-6635.

Jing, H., Vakoc, C. R., Ying, L., et al. (2008). Exchange of GATA factors mediates transitions in looped chromatin organization at a developmentally regulated gene locus. Mol Cell 29, 232-242.

Kacem, S. and Feil, R. (2009). Chromatin mechanisms in genomic imprinting. Mamm Genome 20, 544-556.

Kahn, S. D. (2011). On the future of genomic data. Science 331, 728-729.

Karimi, M., Johansson, S., and Ekstrom, T. J. (2006). Using LUMA: a Luminometric-based assay for global DNA-methylation. Epigenetics 1, 45-48.

Karpf, A. R. and Matsui, S. (2005). Genetic disruption of cytosine DNA methyltransferase enzymes induces chromosomal instability in human cancer cells. Cancer Res 65, 8635-8639.

Kasowski, M., Grubert, F., Heffelfinger, C., et al. (2010). Variation in transcription factor binding among humans. Science 328, 232-235.

Kato, S. and Fujiki, R. (2011). Transcriptional controls by nuclear fat-soluble vitamin receptors through chromatin reorganization. Biosci Biotechnol Biochem 75, 410-413.

Kauppi, L., Jeffreys, A. J., and Keeney, S. (2004). Where the crossovers are: recombination distributions in mammals. Nat Rev Genet 5, 413-424.

Kim, D. H., Villeneuve, L. M., Morris, K. V., et al . (2006). Argonaute-1 directs siRNA-mediated transcriptional gene silencing in human cells. Nat Struct Mol Biol 13, 793-797.

Kim, J. H., Rozek, L. S., Soliman, A. S., et al. (2013). Bisphenol A-associated epigenomic changes in prepubescent girls: a cross-sectional study in Gharbiah, Egypt. Environ Health 12,33 .

Klose, R. J. and Bird, A. P. (2006). Genomic DNA methylation: the mark and its mediators. Trends Biochem Sci 31, 89-97.

Krauss, V. and Reuter, G. (2011). DNA methylation in Drosophila - a critical evaluation. Prog Mol Biol Transl Sci 101, 177-191.

LaSalle, J. M. and Lalande, M. (1996). Homologous association of oppositely imprinted chromosomal domains. Science 272 , 725-728.

Laurent, L., Wong, E., Li, G., et al. (2010). Dynamic changes in the human methylome during differentiation. Genome Res 20,320-331. 
LeBaron, M. J., Rasoulpour, R. J., Klapacz, J., et al. (2010). Epigenetics and chemical safety assessment. Mutat Res 705, 83-95.

Lee, G. Y., Kenny, P. A., Lee, E. H., et al. (2007). Three-dimensional culture models of normal and malignant breast epithelial cells. Nat Methods 4, 359-365.

Lin, Z., Reierstad, S., Huang, C. C., et al. (2007). Novel estrogen receptor-alpha binding sites and estradiol target genes identified by chromatin immunoprecipitation cloning in breast cancer. Cancer Res 67, 5017-5024.

Lindeman, L. C., Vogt-Kielland, L. T., Alestrom, P., et al. (2009). Fish'n ChIPs: chromatin immunoprecipitation in the zebrafish embryo. Methods Mol Biol 567, 75-86.

Linney, E., Donerly, S., Mackey, L., et al. (2011). The negative side of retinoic acid receptors. Neurotoxicol and Teratol 33, 631-640.

Lister, R., Pelizzola, M., Dowen, R. H., et al. (2009). Human DNA methylomes at base resolution show widespread epigenomic differences. Nature 462, 315-322.

Manikkam, M., Tracey, R., Guerrero-Bosagna, C., and Skinner, M. K. (2013). Plastics derived endocrine disruptors (BPA, DEHP and DBP) induce epigenetic transgenerational inheritance of obesity, reproductive disease and sperm epimutations. PLoS One 8, 55387.

Mardis, E. R. (2006). Anticipating the 1,000 dollar genome. Genome Biol 7, 112.

McCollum, C. W., Ducharme, N. A., Bondesson, M., et al. (2011). Developmental toxicity screening in zebrafish. Birth Defects Res C Embryo Today 93, 67-114.

McDaniell, R., Lee, B. K., Song, L., et al. (2010). Heritable individual-specific and allele-specific chromatin signatures in humans. Science 328, 235-239.

Meissner, A., Mikkelsen, T. S., Gu, H., et al. (2008). Genomescale DNA methylation maps of pluripotent and differentiated cells. Nature 454, 766-770.

Mikkelsen, T. S., Ku, M., Jaffe, D. B., et al. (2007). Genomewide maps of chromatin state in pluripotent and lineage-committed cells. Nature 448, 553-560.

Mishima, Y. (2012). Widespread roles of microRNAs during zebrafish development and beyond. Dev Growth Differ 54, $55-65$.

Morris, K. V., Chan, S. W., Jacobsen, S. E., et al. (2004). Small interfering RNA-induced transcriptional gene silencing in human cells. Science 305, 1289-1292.

Nagalakshmi, U., Wang, Z., Waern, K., et al. (2008). The transcriptional landscape of the yeast genome defined by RNA sequencing. Science 320, 1344-1349.

Niculescu, M. D. and Zeisel, S. H. (2002). Diet, methyl donors and DNA methylation: interactions between dietary folate, methionine and choline. J Nutr 132, 2333S-2335S.

O’Malley, B. W., Qin, J., and Lanz, R. B. (2008). Cracking the coregulator codes. Curr Opin Cell Biol 20,310-315.

OECD - Organisation for Economic Co-operation and Development (2011). Validation Report (Phase 1) for the Zebrafish embryo toxicity Test Part I, Series on Testing and Assessment $n^{\circ}$ 157. OECD, Paris.
OECD (2012a). Series on Testing and Assessment: No 178: Detailed Review Paper on the State of the Science on Novel In vitro and In vivo Screening and Testing Methods and Endpoints for Evaluating Endocrine Disruptors. ENV/JM/ MONO(2012)23, 213 pp.

OECD (2012b). Series on Testing and Assessment: No 150: Guidance Document on Standardised Test Guidelines for Evaluating Chemicals for Endocrine Disruption. ENV/JM/ MONO(2012)22, 524 pp.

OECD (2013). Test No. 236: Fish Embryo Acute Toxicity (FET) Test. OECD Guidelines for the Testing of Chemicals, Section 2, OECD Publishing.

Peters, A. H., Mermoud, J. E., O’Carroll, D., et al. (2002). Histone H3 lysine 9 methylation is an epigenetic imprint of facultative heterochromatin. Nat Genet 30, 77-80.

Pikaard, C. S. (2006). Cell biology of the Arabidopsis nuclear siRNA pathway for RNA-directed chromatin modification. Cold Spring Harb Symp Quant Biol 71, 473-480.

Pogribny, I. P., Tryndyak, V. P., Boureiko, A., et al. (2008). Mechanisms of peroxisome proliferator-induced DNA hypomethylation in rat liver. Mutat Res 644, 17-23.

Prins, G. S., Ye, S. H., Birch, L., et al. (2011). Serum bisphenol A pharmacokinetics and prostate neoplastic responses following oral and subcutaneous exposures in neonatal SpragueDawley rats. Reprod Toxicol 31, 1-9.

Ptashne, M. (2013). Faddish stuff: Epigentics and the inheritance of acquired characteristics. FASEB J 27, 1-2.

Rasoulpour, R. J., LeBaron, M. J., Ellis-Hutchings, R. G., et al. (2011). Epigenetic screening in product safety assessment: are we there yet? Toxicol Mech Methods 21, 298-311.

Rassoulzadegan, M., Grandjean, V., Gounon, P., et al. (2006). RNA-mediated non-mendelian inheritance of an epigenetic change in the mouse. Nature 441, 469-474.

Reik, W., Dean, W., and Walter, J. (2001). Epigenetic reprogramming in mammalian development. Science 293, 10891093.

Renner, R. (2009). Key environmental epigenetics paper challenged. Environ Sci Technol 43, 8009-8010.

Rohwedel, J., Guan, K., Hegert, C., et al. (2001). Embryonic stem cells as an in vitro model for mutagenicity, cytotoxicity and embryotoxicity studies: present state and future prospects. Toxicol In Vitro 15, 741-753.

Ronis, M. J., Chen, Y., Liu, X., et al. (2011). Enhanced expression and glucocorticoid-inducibility of hepatic cytochrome $\mathrm{P} 450$ 3A involve recruitment of the pregnane-X-receptor to promoter elements in rats fed soy protein isolate. J Nutr 141, 10-16.

Rosenfeld, C. S., Sieli, P. T., Warza, D. A., et al. (2013). Maternal exposure to bisphenol A and genistein has minimal effect on A(vy)/a offspring coat color but favors birth of agouti over nonagouti mice. Proc Natl Acad Sci U S A 110, 537-542.

Roy, D., Yu, K., and Lieber, M. R. (2008). Mechanism of Rloop formation at immunoglobulin class switch sequences. Mol Cell Biol 28, 50-60.

Rozowsky, J., Euskirchen, G., Auerbach, R. K., et al. (2009). PeakSeq enables systematic scoring of ChIP-seq experiments 
relative to controls. Nat Biotechnol 27, 66-75.

Santenard, A., Ziegler-Birling, C., Koch, M., et al. (2010). Heterochromatin formation in the mouse embryo requires critical residues of the histone variant H3.3. Nat Cell Biol 12, 853862.

Sapienza, C., Paquette, J., Tran, T. H., et al. (1989). Epigenetic and genetic factors affect transgene methylation imprinting. Development 107, 165-168.

Sarter, B., Long, T. I., Tsong, W. H., et al. (2005). Sex differential in methylation patterns of selected genes in Singapore Chinese. Hum Genet 117, 402-403.

Sboner, A., Mu, X. J., Greenbaum, D., et al. (2011). The real cost of sequencing: higher than you think! Genome Biol 12, 125.

Schmieder, P. K., Tapper, M. A., Denny, J. S., et al. (2004). Use of trout liver slices to enhance mechanistic interpretation of estrogen receptor binding for cost-effective prioritization of chemicals within large inventories. Environ Sci Technol 38, 6333-6342.

Schneider, S., Kaufmann, W., Buesen, R., et al. (2008). Vinclozolin - the lack of a transgenerational effect after oral maternal exposure during organogenesis. Reprod Toxicol 25, 352-360.

Schwartz, S. and Ast, G. (2010). Chromatin density and splicing destiny: on the cross-talk between chromatin structure and splicing. EMBO J 29, 1629-1636.

Sigurdsson, M. I., Smith, A. V., Bjornsson, H. T., et al. (2009). HapMap methylation-associated SNPs, markers of germline DNA methylation, positively correlate with regional levels of human meiotic recombination. Genome Res 19, 581-589.

Simmons, R. (2008). Perinatal programming of obesity. Semin Perinatol 32, 371-374.

Skinner, M. K. (2008). What is an epigenetic transgenerational phenotype? F3 or F2. Reprod Toxicol 25, 2-6.

Song, L. and Crawford, G. E. (2010). DNase-seq: a high-resolution technique for mapping active gene regulatory elements across the genome from mammalian cells. Cold Spring Harb Protoc 2010, pdb prot5384.

Stokes, W. S. (2004). Selecting appropriate animal models and experimental designs for endocrine disruptor research and testing studies. ILAR J 45, 387-393.

Stouder, C. and Paoloni-Giacobino, A. (2010). Transgenerational effects of the endocrine disruptor vinclozolin on the methylation pattern of imprinted genes in the mouse sperm. Reproduction 139, 373-379.

Sugii, S. and Evans, R. M. (2011). Epigenetic codes of PPARgamma in metabolic disease. FEBS Lett 585, 2121-2128.

Sugiura-Ogasawara, M., Ozaki, Y., Sonta, S., et al. (2005). Exposure to bisphenol A is associated with recurrent miscarriage. Hum Reprod 20, 2325-2329.

Susiarjo, M., Sasson, I., Mesaros, C., and Bartolomei, M. S. (2013). Bisphenol a exposure disrupts genomic imprinting in the mouse. PLoS Genet 9, e1003401.

Suzuki, M., Jing, Q., Lia, D., et al. (2010). Optimized design and data analysis of tag-based cytosine methylation assays. Genome Biol 11, R36.

Tang, W. Y., Morey, L. M., Cheung, Y. Y., et al. (2012). Neonatal exposure to estradiol/bisphenol A alters promoter methylation and expression of Nsbp 1 and Hpcal1 genes and transcriptional programs of $\mathrm{Dnmt} 3 \mathrm{a} / \mathrm{b}$ and $\mathrm{Mbd} 2 / 4$ in the rat prostate gland throughout life. Endocrinology 153, 42-55.

Thompson, R. F., Atzmon, G., Gheorghe, C., et al. (2010a). Tissue-specific dysregulation of DNA methylation in aging. Aging Cell 9, 506-518.

Thompson, R. F., Fazzari, M. J., Niu, H., et al. (2010b). Experimental intrauterine growth restriction induces alterations in DNA methylation and gene expression in pancreatic islets of rats. J Biol Chem 285, 15111-15118.

Tilgner, H., Nikolaou, C., Althammer, S., et al. (2009). Nucleosome positioning as a determinant of exon recognition. Nat Struct Mol Biol 16, 996-1001.

Udvadia, A. J. and Linney, E. (2003). Windows into development: historic, current, and future perspectives on transgenic zebrafish. Dev Biol 256, 1-17.

Vakoc, C. R., Mandat, S. A., Olenchock, B. A., et al. (2005). Histone H3 lysine 9 methylation and HP1 gamma are associated with transcription elongation through mammalian chromatin. Mol Cell 19, 381-391.

Vandegehuchte, M. B. and Janssen, C. R. (2011). Epigenetics and its implications for ecotoxicology. Ecotoxicology 20, 607-624.

vom Saal, F. S. and Hughes, C. (2005). An extensive new literature concerning low-dose effects of bisphenol A shows the need for a new risk assessment. Environ Health Perspect 113, 926-933.

Waddington, C. H. (1942). The epigenotype. Endeavour 1, 1820.

Waterland, R. A. and Jirtle, R. L. (2003). Transposable elements: targets for early nutritional effects on epigenetic gene regulation. Mol Cell Biol 23, 5293-5300.

Waterland, R. A., Dolinoy, D. C., Lin, J. R., et al. (2006). Maternal methyl supplements increase offspring DNA methylation at Axin Fused. Genesis 44, 401-406.

Weng, Y. I., Hsu, P. Y., Liyanarachchi, S., et al. (2010). Epigenetic influences of low-dose bisphenol A in primary human breast epithelial cells. Toxicol Appl Pharmacol 248, 111-121.

WHO/IPCS - World Health Organization/International Programme on Chemical Safety (2002). Global Assessment of the State-of-the-science of Endocrine Disruptors. WHO/PCS/ EDC/02.2, $180 \mathrm{pp}$.

WHO/UNEP - World Health Organization/United Nations Environment Programme (2013). State of the science of endocrine disrupting chemicals - 2012. An assessment of the state of the science of endocrine disruptors prepared by a group of experts for the United Nations Environment Programme (UNEP) and WHO. pp 296. ISBN: 9789241505031

Whitehead, J., Pandey, G. K., and Kanduri, C. (2009). Regulation of the mammalian epigenome by long noncoding RNAs. Biochim Biophys Acta 1790, 936-947.

Wild, L., Funes, J. M., Boshoff, C., et al. (2010). In vitro transformation of mesenchymal stem cells induces gradual genomic hypomethylation. Carcinogenesis 31, 1854-1862.

Wu, S., Zhu, J., Li, Y., et al. (2010a). Dynamic epigenetic chang- 
es involved in testicular toxicity induced by di-2-(ethylhexyl) phthalate in mice. Basic Clin Pharmacol Toxicol 106, 118123.

Wu, S., Zhu, J., Li, Y., et al. (2010b). Dynamic effect of di2-(ethylhexyl) phthalate on testicular toxicity: epigenetic changes and their impact on gene expression. Int $J$ Toxicol 29, 193-200.

Wu, S. F., Zhang, H., Hammoud, S. S., et al. (2011). DNA methylation profiling in zebrafish. Methods Cell Biol 104, 327-339.

Yamashita, S., Hosoya, K., Gyobu, K., et al. (2009). Development of a novel output value for quantitative assessment in methylated DNA immunoprecipitation- $\mathrm{CpG}$ island microarray analysis. DNA Res 16, 275-286.

Yang, A. S., Estecio, M. R., Doshi, K., et al. (2004). A simple method for estimating global DNA methylation using bisulfite PCR of repetitive DNA elements. Nucleic Acids Res 32, e38.

Yaoi, T., Itoh, K., Nakamura, K., et al. (2008). Genome-wide analysis of epigenomic alterations in fetal mouse forebrain after exposure to low doses of bisphenol A. Biochem Biophys Res Commun 376, 563-567.

Yeo, M., Berglund, K., Hanna, M., et al. (2013). Bisphenol A delays the perinatal chloride shift in cortical neurons by epigenetic effects on the Kcc2 promoter. Proc Natl Acad Sci U $S$ A $110,4315-20$.

Zama, A. M. and Uzumcu, M. (2009). Fetal and neonatal exposure to the endocrine disruptor methoxychlor causes epigenetic alterations in adult ovarian genes. Endocrinology 150, 4681-4691.

Zhang, J. and Lazar, M. A. (2000). The mechanism of action of thyroid hormones. Annu Rev Physiol 62, 439-466.

Zhang, J. J., Zhang, L., Zhou, K., et al . (2011). Analysis of global DNA methylation by hydrophilic interaction ultra highpressure liquid chromatography tandem mass spectrometry. Analytical Biochem 413, 164-70

Zhang, X. and Ho, S. M. (2011). Epigenetics meets endocrinology. J Mol Endocrinol 46, R11-32.

Zilberman, D. and Henikoff, S. (2007). Genome-wide analysis of DNA methylation patterns. Development 134, 3959-3965.

Zofall, M. and Grewal, S. I. (2006). RNAi-mediated heterochromatin assembly in fission yeast. Cold Spring Harb Symp Quant Biol 71, 487-496.

\section{Acknowledgements}

The authors gratefully acknowledge the close cooperation, support and review of the members of the OECD Endocrine Disruptor Testing and Assessment Advisory Group (EDTA-AG), the European Commission, the OECD Secretariat Administrator, Nathalie Delrue, and the helpful comments of the anonymous manuscript reviewers. JMG was supported by an OECD/ European Commission funded consultancy for the preparation of this paper.

\section{Correspondence to}

Miriam N. Jacobs

European Food Safety Authority - EFSA

Scientific Committee and Emerging Risks Unit

Via Carlo Magno 1A

43126 Parma, Italy

Phone: +390521036720

Fax: + 3905210360720

e-mail: miriam.jacobs@efsa.europa.eu

From November 2013:

Miriam N. Jacobs

Public Health England

Centre for Radiation, Chemical and Environmental Hazards

Toxicology Department

Chilton

Oxfordshire

OX11 0RQ

UK

e-mail:miriam.jacobs@phe.gov.uk 